\title{
Nanoparticles Containing Insoluble Drug for Cancer Therapy
}

\author{
Shutao Guo and Leaf Huang* \\ Division of Molecular Pharmaceutics and Center for Nanotechnology in Drug Delivery, Eshelman \\ School of Pharmacy, University of North Carolina at Chapel Hill, Chapel, Hill, NC 27599
}

\begin{abstract}
Nanoparticle drug formulations have been extensively researched and developed in the field of drug delivery as a means to efficiently deliver insoluble drugs to tumor cells. By mechanisms of the enhanced permeability and retention effect, nanoparticle drug formulations are capable of greatly enhancing the safety, pharmacokinetic profiles and bioavailability of the administered treatment. Here, the progress of various nanoparticle formulations in both research and clinical applications is detailed with a focus on the development of drug/gene delivery systems. Specifically, the unique advantages and disadvanges of polymeric nanoparticles, liposomes, solid lipid nanoparticles, nanocrystals and lipid-coated nanoparticles for targeted drug delivery will be investigated in detail.
\end{abstract}

\section{Keywords}

Nanoparticle; drug delivery; lipid; calcium phosphate; nanocrystals; siRNA; polymer; gold nanoparticle; liposome

\section{Introduction}

Over the past two decades, nanomedicine has emerged as a catalyst for the advancement of new pharmaceutical formulations (Ferrari, 2005; Panyam and Labhasetwar, 2003; Shi et al., 2010). By permitting the dispersion of insoluble drugs in aqueous solution, many drugs previously abandoned due to their poor solubility in water can be deemed clinically applicable through encapsulation in a nanocarrier. Nanomedicine can also improve the pharmacokinetics (PK) and biodistribution of drugs that have already been approved for use by the Food and Drug Administration (FDA) (Emerich and Thanos, 2007; Sahoo and Labhasetwar, 2003). By favorably altering the PK of drugs in vivo, nanomedicine can significantly improve the safety of existing chemotherapy regimens.

Several strategies have been successfully developed to formulate nanoparticles (NPs) containing insoluble drugs. Polymers, such as poly (d,l-lactide-co-glycolide) (PLGA) (Bala et al., 2004; Cheng et al., 2007), polylactides (PLA) (Smith, 1986; Soppimath et al., 2001) and polycaprolactone (PCL) (Cai et al., 2007; Park et al., 2005), encapsulate hydrophobic

(c) 2013 Elsevier Inc. All rights reserved

*Address correspondence to: Dr. Leaf Huang, Division of Molecular Pharmaceutics, and Center for Nanotechnology in Drug Delivery, Eshelman School of Pharmacy, University of North Carolina, Chapel Hill, NC 27599, USA. leafh@ unc.edu, Tel.: + 1919 843 0736; fax: + 19199660197.

Publisher's Disclaimer: This is a PDF file of an unedited manuscript that has been accepted for publication. As a service to our customers we are providing this early version of the manuscript. The manuscript will undergo copyediting, typesetting, and review of the resulting proof before it is published in its final citable form. Please note that during the production process errors may be discovered which could affect the content, and all legal disclaimers that apply to the journal pertain. 
drugs through hydrophobic interactions. Through these methods, efficient delivery of both paclitaxel and docetaxel has been achieved (Fonseca et al., 2002; Hrkach et al., 2012).

In addition, liposomes may also be exploited for targeted drug delivery and have been established as the most successful drug carriers marked by their biodegradability and ability to deliver drugs with a wide range of physical properties. More than ten liposomal formulations have been approved for use by the FDA and/or other regulatory authorities and several additional liposomal formulations are currently in clinical trial (Wang et al., 2012). Significant effort is also being made to deliver drugs using inorganic nanoparticles. The development of these nanoparticulate formulations will be reviewed and summarized in Table 1 and Table 2.

\section{Polymeric nanoparticles}

Polymeric nanoparticles can be synthesized through various methods depending on the intended application and drug type. These methods include emulsion diffusion, nanoprecipitation and emulsion evaporation (Jain, 2000; Kumari et al., 2010; Vauthier and Bouchemal, 2009). However, the majority of polymeric nanoparticles are formulated through a self-assembly process using hydrophilic and hydrophobic block copolymers (Adams et al., 2003; Rösler et al., 2001). During the self-assembly of polymeric nanoparticles, the hydrophobic drugs are encapsulated into the core of core-shell nanostructure via hydrophobic interactions. Typically, the final nanoparticles created from this method are 100-200 nm in diameter (Lalatsa et al., 2012; Wang and Grayson, 2012).

Polymeric nanoparticles act as drug depots characterized by controlled release of the encapsulated drug. Modification of the nanoparticles with a surface coating of polyethylene glycol (i.e. PEGylation), enables the nanoparticles' evasion of the reticuloendothelial system (RES) and prolongs circulation in the bloodstream (Esmaeili et al., 2008). This capability, along with the biocompatibility and low immunogenicity of these nanoparticles make them an attractive delivery system, particularly for protein-based and anti-cancer drugs, as well as nucleic acids.

Among the polymers, PLA and PLGA, have been the most extensively investigated for use in drug delivery due to their biocompatibility and controlled release through the hydrolysis of the ester bonds (Li et al., 2011; Makadia and Siegel, 2011). By adjusting the composition of PLGA through alteration of the ratio between lactide and glycolide, the release rate of drugs can be adjusted from a scale of days to months (Amann et al., 2010; Faisant et al., 2002; Ramchandani and Robinson, 1998). However, there are only a few polymeric nanoparticulate formulations on the market. One of them, paclitaxel-loaded nanoparticles (Genexol-PM®) composed of an amphiphilic diblock copolymer, monomethoxypoly(ethylene glycol)-block-poly(D,L-lactide) (mPEG-PDLLA) and paclitaxel is approved for the treatment of breast and lung cancers in Asia (Lee et al., 2008b; Lim et al., 2010). The data demonstrated that Genexol-PM® showed significant antitumor activity with an increased maximum tolerated dose thus allowing the administration of higher doses of paclitaxel. Genexol-PM® has also been combined with gemcitabine and cisplatin to treat patients with advanced urothelial cancer in Phase II clinical studies (Lee et al., 2012a). Additionally, Phase I clinical trial have been completed on PEG-PLGA-PMSA-targeted polymeric NPs loaded with Docetaxel (BIND-014) (Cartwright, 2013; Prabhakar et al., 2013; Wang, Langer, 2012). The trial have indicated that the formulation is safe with a reasonable maximum tolerated dose and notable anti-tumor activity. A similar formulation of a docetaxel-polymeric micellar nanoparticle formulation (Docetaxel-PNP) is currently under development by Samyang Pharmaceuticals undergoing Phase I clinical trial to treat advanced solid malignancies in Korea (Miller and Wang, 2013; Svenson, 2012). 
In the United States, non-biodegradable poloxamer is approved by the FDA and has been widely used to develop nanomedicines (Chang et al., 2011; Schmolka, 1991). SP1049C, composed of poloxamer and doxorubicin (Valle et al., 2011) is particularly active in treating multidrug resistant (MDR) and metastatic cancers (Danson et al., 2004; Dumortier et al., 2006); the poloxamer disrupts mitochondrial functionality in chemo-resistant cells by depleting ATP and releasing reactive oxygen species (ROS) and cytochrome C. Currently, SP1049C is advancing to an international Phase III clinical study. Likewise, similar formulations containing docetaxel (SP1012C) and cabazitaxel (SP1015C) are being evaluated in preclinical studies (Svenson, 2012).

Kataoka et al. esterified a PEG-polyaspartate block copolymer using 4-phenyl-1-butanol to enhance the hydrophobicity of copolymer and its compatibility with paclitaxel (Negishi et al., 2006). The amphiphilic copolymer was used to construct a micellar paclitaxel (PTX) formulation named NK105. For the micellar drug formulation, NK105 was characterized with a drug loading of $23 \mathrm{wt} \%$. It has been observed that PEGylation significantly improves the area-under-curve (AUC) values in the blood and in the tumor by 90 - and 25 -fold, respectively, compared to free drug. NK105 showed superior anti-tumor efficacy and reduced neurotoxicity when compared with free PTX. Results from Phase I clinical studies showed that NK105 was well tolerated (Hamaguchi et al., 2007). Efficacy and safety studies in Phase II clinical trial showed that NK105 was very efficacious in treating patients with previously treated advanced gastric cancer (Ko et al., 2013). Due to the success of this formulation, a Phase III clinical trial of NK105 is currently underway.

Another promising polymeric nanoparticle formulation is nab-paclitaxel (Abraxane) (Green et al., 2006; Miele et al., 2009). Abraxane is an albumin-bound paclitaxel nanoparticle specifically designed to replace Taxol in an effort to reduce the highly toxic side effects induced when Taxol is formulated in a 1:1 (v:v) mixture of Cremophor EL and dehydrated alcohol. Compared to Taxol, Cremophor $($-free Abraxane decreases the both the number and severity of side effects induced by paclitaxel (Micha et al., 2006). Clinical results show that Abraxane also induces higher response rates and shows prolonged tumor suppressive activity without increased toxicity in patients with metastatic breast cancer. In light of these discoveries, the FDA approved Abraxane for clinical use in January 2005. Thereafter, several drug-albumin nanoparticulate formulations were developed based on the same technology and are currently advancing to clinical trials.

In a Phase I/II study, Abraxane was combined with gemcitabine to treat pancreatic cancer. The combination showed significant anti-pancreatic cancer efficacy with a $48 \%$ response rate observed at MTD. This study also indicated the significance of SPARC up-regulation, which was reported to dictate the uptake of drugs into tumor cells and is primarily responsible for the tumor's sensitivity to drug treatment. It was hypothesized nab paclitaxel significantly enhanced the bioavailability of gemcitabine inside tumors through Abraxane targeting to deplete stroma and therefore enhance the penetration of gemcitabine inside the pancreatic cancer cells (Neuzillet et al., 2013; Von Hoff et al., 2011). Recently disclosed data from the Phase III clinical study demonstrated that the combination permitted a significant improvement in efficacy and response rate over free gemcitabine alone (Von Hoff et al., 2012).

\section{Polymer-drug conjugate nanoparticles}

Although polymeric nanoparticles have shown promising potential for drug delivery, the achievable drug loading in polymeric nanoparticles varies significantly and limits the broad application of this versatile platform. To maximize the loading of drugs in polymeric nanoparticles, the drug and carrier must be perfectly matched in miscibility (Liu et al., 2004; 
Xiong et al., 2011). Many efforts have been made to modify the polymer backbone with an aim of improving the miscibility between drugs and carriers evaluated using the FlouryHuggins interaction parameter $\left(\chi_{\mathrm{drug} / \text { polymer }}\right)$. It is believed that a smaller interaction parameter indicates a higher miscibility between the drug and carrier. In addition, the drug loading of a polymeric nanoparticle formulation can be greatly enhanced through variation of the select polymer's side group. Unfortunately for FDA approved poly(lactic-co-glycolic) acid (PLGA) NPs, the available options for modification are greatly limited as the polymer contains only one functional terminal group. In an effort to maximize the drug loading capacity of polymeric nanoparticles while enhancing miscibility and biocompatibility, a polymeric drug conjugate has been developed as an alternative method.

In the same method that amphiphilic polymers are capable of undergoing self-assembly into core-shell nanoparticle formulations hydrophilic copolymers conjugated with hydrophobic drugs become amphiphilic and can be self-assembled into nanoparticles. To date, the most often-used hydrophilic polymers are HPMA (Duncan et al., 2001; Kopeček et al., 2000), Dextran (Kojima et al., 1980; Mitra et al., 2001) and poly-glutamic acid (Li, 2002; Singer et al., 2004). Several conjugates based on these copolymers are under clinical evaluation, such as PK1 (Seymour et al., 2009), Xyotax ${ }^{\mathrm{TM}}$ (Opaxio ${ }^{\mathrm{TM}}$ or CT-2103) (O'Brien et al., 2008), CT-2106 (Homsi et al., 2007), Delimotecan (MEN 4901/T-0128) (Veltkamp et al., 2008) and DOX-OXD (AD-70) (Danhauser-Riedl et al., 1993). Kopecek and colleagues first developed the HPMA-doxorubicin conjugate with a drug loading capacity of approximately 8wt.\%(Duncan et al., 1987). Later, HPMA-doxorubicin (PK1, FCE28068) entered into a Phase II clinical trial (Seymour et al., 2009). Additionally, a biodegradable, polyglutamic acid-paclitaxel conjugate with a drug content of $37 \mathrm{wt} . \%$ has also been synthesized (Auzenne et al., 2002; Li et al., 1998)and conjugates of PGA with camptothecin were developed and are currently under clinical evaluation (Bhatt et al., 2003; Homsi, Simon, 2007). However, with the exception of PGA-paclitaxel conjugates (Xyotax), polymer-drug conjugates are often plagued by the slow release of active drugs and the subsequent side effects as observed in clinical trial (Li and Wallace, 2008; Lin et al., 2007; Sabbatini et al., 2004). Despite the advantages, Xyotax can only improve the rate of cancer survival in women, but not in men (Ross et al., 2006). This result may be because estrogen promotes the degradation of the backbone of polyglutamic acid (Ross, Bonomi, 2006). These findings therefore inspired the development of conjugates for controlled drug release. Thereafter, many efforts have been made to tailor the conjugate using $\mathrm{pH}$-sensitive or enzyme degradable linkers (Duncan, 2006; Saito et al., 2003).

Albumin is a very promising material for use in drug delivery due to its biodegradability and availability, as well as its non-immunogenic nature. Resulting from these properties, albumin has demonstrated preferential uptake by both tumor and inflamed tissues (Elzoghby et al., 2012; Kratz, 2008). Methotrexate-albumin conjugate (MTX-HSA) was the first albumin conjugate that was evaluated in Phase I/II clinical studies (Bolling et al., 2006; Hartung et al., 1999; Vis et al., 2002). However, there has been no further progress in examining the effects of this conjugate. In addition, Kratz et al. synthesized a series of drugalbumin conjugates using enzymatically cleavable peptide linkers to achieve conjugates with precise structures. Some examples include doxorubicin-albumin-, methotrexate-, and camptothecin-conjugates which are each cleaved by a unique combination utilizing two to three of the following: matrix metalloproteases 2 and 9, cathepsin B, urokinase, prostatespecific antigen (PSA), plasmin or proteases (Kratz, 2008; Warnecke et al., 2007).

Davis et al. developed a cyclodextrin-containing polymer-camptothecin (CPT) drug conjugate where $10 \mathrm{wt} \%$ of CPT was conjugated to the polymer through the glycine amino acid linker with minimal side effects (Cheng et al., 2003). The drug was conjugated via selfassembly to form nanoparticles. The formulation (formerly called IT-101, now CRLX101) 
has an average size between $30-40 \mathrm{~nm}$. The slightly negatively charged IT-101 showed a plasma half-life of about $24 \mathrm{~h}$ in blood circulation and significant tumor accumulation within the first 24h following IV injection (Schluep et al., 2006a; Schluep et al., 2006b; Schluep et al., 2009). Preclinical data showed that a single IV dose of IT-101 (18.3 mg eq. CPT/kg) exhibited comparable efficacy to three weekly doses of Irinotecan (100 mg/kg IP) with significantly lower toxicity. Data from Phase I clinical trial reported that the half-life of IT-101 in subjects was $\sim 40 \mathrm{~h}$ while the formulation also improved the tolerability and efficacy towards CPT (Svenson et al., 2011). A Phase II clinical trial of IT-101 is currently underway.

Recently, Li et al. (Ernsting et al., 2012a; Ernsting et al., 2012b) developed a docetaxelacetylated carboxymethylcellulose drug conjugate (Cellax). The drug conjugate was characterized with a drug loading of $37.3 \mathrm{wt} \%$ and was able to form nanoparticles via selfassembly. Preclinical data has shown that PEGylated Cellax has extended circulation time in the blood over Abraxane and no significant drug release in the blood was observed. Cellax showed significantly higher tumor accumulation than Abraxane through the EPR effect. One single IV injection of Cellax significantly suppressed the growth of a panel of primary and metastatic tumors and extended the survival of tumor bearing mice without observable adverse effects. A further study of the mechanism behind the anti-tumor effects showed that Cellax can reduce the content of a-smooth muscle actin (a-SMA), which is a marker of the cancer-associated fibroblasts, in 4T1 and MDA-MB-231 orthotopic breast tumor models (Murakami et al., 2013). Cellax treatment significantly decreased the tumor IFP. As a result, perfusion of active drugs into tumors was significantly enhanced resulting in tumor growth inhibition. These studies indicated the importance of overcoming stroma-induced barriers in cancer treatment.

\section{Liposomal formulation}

As described by Bangham in 1964 (Bangham and Horne, 1964), liposomes formed from amphiphilic phospholipids and cholesterol became one of the first nanoparticulate platforms for drug delivery. When the lipid film is hydrated, the hydrophobic drugs can be successfully incorporated in a bilayer of liposomes. Additionally, the liposomes may be used to encapsulate water-soluble drugs into the internal aqueous core. By varying the combination of lipids used in formulating the nanoparticles, the biodistribution in vivo can be precisely adjusted to optimize tumor accumulation.

PEGylation is the most effective method for reducing protein adsorption in vivo and can successfully facilitate the particles' avoidance of the RES system to prolong their circulation in the bloodstream (Guo and Huang, 2011; Klibanov et al., 1990). PEG-lipids (e.g. PEGDSPE) are usually inserted into the liposomes to form a hydrated layer on the liposome surface. Typically, liposomes can improve a drug's pharmacokinetics and biodistribution. Liposomes that are 100-200 $\mathrm{nm}$ in diameter readily accumulate in the tumor interstitium because of the enhanced permeability and retention (EPR) effect (Fang et al., 2011; Maeda et al., 2000). The EPR effect is also facilitated by the lack of a draining lymphatic system in the tumor tissue.

Doxorubicin is loaded into liposomes using remote loading technology (Barenholz, 2012; Fritze et al., 2006). The loaded drug crystalizes inside the liposomes due to low solubility and high concentration. In patients, Doxil (liposomal doxorubicin) prolongs the circulation of doxorubicin, as well as increases its concentration in the tumors while decreasing its concentration in normal tissues, such as the heart (Gabizon et al., 2003). Doxil significantly decreases the cardio-toxicity of doxorubicin and showed comparable anti-tumor efficacy with doxorubicin in many types of cancer. Following the success of Doxil (Barenholz, 
2012), the FDA approved non-PEGylated doxorubicin liposomal formulation DaunoXome (Fassas and Anagnostopoulos, 2005) and Myocet (Leonard, Williams, 2009) for cancer therapy. There are more than 11 additional formulations approved for clinical use, with many more in clinical and preclinical development (Duffaud, Borner, 2004; Ko, Tempero, 2013; Koudelka and Turanek, 2012; May and Li, 2013; Roy, Park, 2013; Svenson, 2012; Tagami et al., 2012; Wang, Langer, 2012). Among them, ThermoDox is a very promising doxorubicin formulation and currently undergoing Phase III clinical trial for the treatment of hepatocellular carcinoma (Dromi, Frenkel, 2007). In this formulation, the release of Doxorubicin is triggered by hyperthermic treatments.

NX 211 is a liposomal formulation of lurtotecan and was formulated with methodology similar to that of DaunoXome (Emerson et al., 2000). Clinical Phase II results indicated minimal anti-cancer activity in topotecan resistant ovarian cancer (Seiden et al., 2004). MM-398 (PEP02) is a liposomal nanocarrier formulation of irinotecan. A negatively charged sucrose octasulfate in interior aqueous Phase of liposomes formed electrolytes complexes with positively charged irinotecan and therefore assist the drug loading (Drummond et al., 2006). In clinical Phase II trial, MM-398 extended the median survival of patients who had failed treatment with gemcitabine (Ko, Tempero, 2013; Roy, Park, 2013). Currently, MM-398 is advancing to Phase III to treat patients with gemcitabine (GEM)refractory metastatic pancreatic cancer with combination of 5-fluorouracil and leucovorin.

In addition, a liposomal paclitaxel formulation, LEP-ETU, is also developed (Straubinger and Balasubramanian, 2005). Paclitaxel is entrapped within the liposomal hydrophobic phospholipid bilayers. In Phase I study, LEP-ETU improved the MTD of paclitaxel compared with Taxol®. Phase II trial in treating patients with metastatic breast cancer indicated the safety and efficacy of LEP-ETU (Koudelka and Turanek, 2012).

\section{Solid lipid nanoparticles}

Due to limited space within the bilayer of the liposomes, most of liposomal formulations are characterized by low drug loading. To overcome this issue, solid lipid nanoparticles (SLNs) were developed (Mehnert and Mäder, 2001; Müller et al., 2000). The solid lipid nanoparticulate formulations have many advantages, such as increased safety, high stability and ease of industrial scale-up. SLNs are made of solid lipids, emulsifiers, the encapsulated drugs and water. Generally, the lipids are triglycerides, partial-glyceride-fatty acids, steroids and waxes. A variety of emulsifiers have been used to stabilize the lipid dispersion. SLNs can be prepared by high-pressure homogenization (HPH), high shear mixing, and ultrasound or solvent emulsification/evaporation methods. Many different drugs have been incorporated into SLNs. For example, SLNs formulated with piribedil, vinpocetine and cyclosporine A for oral delivery have a high capacity of drug loading, improving the bioavailability of these drugs (Swathi et al., 2012). Similarly, ubidecarenone's loading capacity can be up to $50 \%$ (Bunjes et al., 2001). Battaglia et al. has also demonstrated SLNs are able to encapsulate methotrexate (Battaglia et al., 2011). In vivo, SLNs enhance the accumulation of drugs in the tumor and increase the therapeutic effects. Although SLNs are being exhaustively used as a platform to deliver hydrophobic anticancer drugs, preclinical research is still being conducted on their properties and effects.

\section{Lipid coated Calcium Phosphate (LCP) nanoparticles}

The applications of nanomedicine are hampered by the low stability and rapid blood clearance of the particles in vivo. For the liposomes, PEG-lipid (such as PEG-DSPE) is usually inserted into liposomes to form a hydrophilic layer on the liposome surface to avoid RES. When inserted, the PEG takes mushroom conformation at low densities and a brush 
conformation at higher densities of DSPE-mPEG (Huang and Liu, 2011). The brush mode is the ideal configuration for protecting nanoparticles from serum absorption. Unfortunately, a high content of the detergent-like PEG-lipid will lyse the liposome. A supporting lipidbilayer and the proper density of PEGylation stabilizes the nanoparticle in the blood and enables the evasion of the RES ( $\mathrm{Li}$ and Huang, 2009).

Calcium phosphate $(\mathrm{CaP})$ is a natural and biocompatible material. Its acid sensitivity allows the release of the entrapped cargo from the acidic endosome into the cytoplasm. Inorganic $\mathrm{CaP}$ NPs can be synthesized through the reaction between calcium and phosphate ions. However, the size and stability of CaP NPs are very difficult to control. Recently, microemulsions have been used as a reactor to synthesize CaP NPs (Muddana et al., 2009), but the NPs were purified using HPLC, process that is tedious and difficult to complete during scale-up. However, when attempting to purify the nanoparticles using a precipitation method, the NPs tend to aggregate with the addition of ethanol. In order to prevent aggregation, we innovatively synthesized lipid-coated CaP NPs (Li et al., 2010; Li, Yang, 2012). During the synthesis of NPs, an amphiphilic, anionic lipid, DOPA, was added into the microemulsion (As shown in Figure 2). The amphiphilic DOPA stays at the interface of the microemulsion and interacts with the synthesized CaP NPs through binding with the surface of NPs. The NPs are then coated with a layer of lipids. DOPA-coated CaP NPs can be purified in a manner similar to that of quantum dots and iron oxide nanoparticles, in particular, and exhibit similar solubility.

The DOPA-coated CaP NPs are freely dispersed in hexane, toluene and chloroform and can be stabilized in aqueous solution by DSPE-PEG and other lipids, such as DOTAP, DOPC and cholesterol. During preparation, anionic imaging agents, nucleic acids (DNA and siRNA) and drugs can be incorporated into the CaP NPs, indicating the theranostic potential of this delivery mechanism (Yang et al., 2011; Zhang et al., 2013). For the delivery of siRNA, the $\mathrm{ED}_{50}$ of LCP NPs encapsulated with HDM2/c-myc/VEGF siRNA is $\sim 0.2 \mathrm{mg} / \mathrm{kg}$ in A549 tumors (Yang, Li, 2011). The combination of the silencing of HDM2/c-myc/VEGFinhibited tumor proliferation and angiogenesis induces tumor apoptosis. In addition, the bioactive form of gemcitabine, gemcitabine triphosphate (GTP), was efficiently loaded into the LCP NPs (Figure 3) (Zhang, Kim, 2013). Therapeutic studies show that anisamidetargeted LCP NPs loaded with GTP effectively delayed tumor growth in human NSCLC $\mathrm{H} 460$ and pancreatic BxPC-3 cancer xenografts, with little toxicity in vivo. This LCP NP platform may inspire the delivery of many more chemo drugs modified with phosphate groups to bypass the kinase phosphorylation process, enabling more potent activity.

\section{Nanocrystals}

To eliminate potential toxicity from the carrier and improve the maximum tolerable dose (MTD), nanocrystals have been developed using the chemo-drugs (Chen et al., 2011; Junghanns and Müller, 2008). The nanocrystals have a size in the nanometer range and crystalline characteristics. The drug loading of the nanoparticles is nearly $100 \%$. There are two major methods used to synthesize nanocrystals, i.e., "top-down" and "bottom-up" methods.

"Bottom-up" methods involve self-assembly in nano-scale (De Waard et al., 2008). Nanoprecipitation is the most popular way to produce nanocrystals; the crystals grow from the nucleation (Gao et al., 2008; Muller and Keck, 2004). Typically, drugs are solubilized in a water miscible solvent, such as a combination of acetone, THF and ethanol, at a level of super saturation in the water. This process allows the rapid formation of nucleation after the water has been added. After the addition of the antisolvent, the nanocrystals are formed with the aid of a stabilizer, such as polyvinylpyrrolidone, Tween 80, Poloxamer 188 or lecithin. 
The stabilizer will inhibit the aggregation of nanocrystals. A second precipitation method is the preparation of amorphous, drug nanoparticles, which was developed by Auweter and Horn (Auweter et al., 1998). The amorphous nanoparticles are prone to partial or complete re-crystallization, resulting in decreased bioavailability. Due to the stability and consistent performance, nanocrystals are preferred over amorphous drug particles. Another bottom-up process is the controlled crystallization of the particles during freeze drying (De Waard, Hinrichs, 2008), which is also considered to be suitable for large-scale production (de Waard et al., 2009).

"Top-down" involves breaking down large drug particles into smaller particles through milling or HPH (Keck and Müller, 2006). In 1992, Liversidge et al. applied milling technology to produce drug particles (Liversidge et al., 1992). The milling chamber is charged with milling pearls, dispersion medium (e.g. water), drug powders and stabilizers. The pearls rotate at a very high speed to generate particles of small sizes. However, erosion from the milling material during the milling process leads to contamination of the drugs. Compared to the manufacture of other nanomedicines, the milling technology allows much larger scale-up production of drug particles and the FDA has approved several formulations that are created with this method.

The development of Dissocubes1 piston-gap homogenizer (SkyePharma) in the mid-1990s has accelerated the application of HPH in the pharmaceutical industry (Keck and Müller, 2006). Typically, HPH is performed in either water or PEG 400 . The non-aqueous media is preferred in the creation of particles with water sensitive drugs. The suspension of crystalline drugs and stabilizers is passed through the homogenizer at high pressure (5002000 bar). The size of the particles is influenced by the stabilizers, the number of cycles and the pressure and temperature of the homogenization process. By increasing the homogenization pressure and the number of homogenization cycles, smaller nanocrystals can be obtained. Stabilizers are used to avoid the aggregation of nanocrystals. To date, Triglide1 has been approved for the treatment of hypercholesterolemia or hyperlipidemia (Tziomalos and Athyros, 2006). In addition, Nanopure, Nanocrystal ${ }^{\mathrm{TM}}$, Nanomorph ${ }^{\mathrm{TM}}$ and Nanoedge ${ }^{\mathrm{TM}}$ have been developed (Keck and Müller, 2006).

Compared to intravenous route, oral administration has higher patient compliance and higher market potential. Several nanocrystal formulations have been approved by FDA as oral products. For oral administration, bioavailability of hydrophobic drugs highly depends on the dissolution rate and its diffusion through the gastrointestinal membranes to the bloodstream. One of the major advantages of nanocrystal in oral delivery is the enhanced solubility of drug and faster dissolution of the nanocrystals due to its high surface-area-tovolume ratio, which can be well explained by Noyes-Whitney equation (Noyes and Whitney, 1897; Shegokar and Muller, 2010). In addition, nanocrystals are biological membrane adhesive and can extend the retention of drug in the gastrointestinal tract. These nanocrystal formulations improved the bioavailability of drug (Shegokar and Muller, 2010). For example, bioavailability of Wellvone was improved 2.5 -fold by administration in atovaquone nanosuspension (Scholer et al., 2001), and Danazol improved the bioavailability of marketed danazol macrosuspension by 15.8 fold(Liversidge and Cundy, 1995). Yet, none of cancer nanocrystal formulations has been approved by FDA (Sun and Yeo, 2012). 2Methoxyestradiol is a natural metabolite of estradiol, targets new blood vessels in tumor and shows anti-angiogenesis effects. It has been formulated as nanocrystal Panzem®NCD and Panzem ${ }^{\circledR N C D}$ enhanced the bioavailability of 2-Methoxyestradiol (Tevaarwerk et al., 2009). In Phase II clinical trial, Panzem ${ }^{\circledR N C D}$ was orally administered in combination with bevacizumab or sunitinib to treat metastatic carcinoid tumors (Bruce, Eickhoff, 2012; Kulke, Chan, 2011). However, Panzem ${ }^{\circledR N C D}$ alone, or in combination, did not induce strong response in patients. Thymectacin, an anticancer prodrug of brivudine monophosphate, is 
formulated as Theralux ${ }^{\mathrm{TM}}$ and being investigated in a Phase I/II trial (Shegokar and Muller, 2010).

\section{Inorganic nanoparticles}

Inorganic nanoparticles, such as magnetic iron oxide nanoparticles, quantum dots and carbon nanotubes, are very attractive for use in drug delivery because of their dual function in diagnosis and therapeutic effect (Sun et al., 2008; Xu et al., 2006).

Iron oxide nanoparticles (IONPs) are nanocrystals made from magnetite or hematite and used as MRI contrast agents (Chertok et al., 2008). Usually, the synthesized IONPs have a thick alkyl coating and are hydrophobic. After ligand exchange, the surface of IONPs can be functionalized for PEGylation and conjugation with drugs and targeting ligands. For instance, methotrexate (MTX), etoposide, doxorubicin and paclitaxel were successfully conjugated, attached or encapsulated into the IONPs for potential treatment of tumors (Hwu et al., 2008; Peng et al., 2008). Kohler et al. delivered methotrexate (MTX) using IONPs to treat breast and brain tumor cells (Kohler et al., 2005). Labhasetwar et al. prepared a doxorubicin/oleic acid (OA)-pluronic-coated iron oxide magnetic nanoparticle formulation (Figure 4) (Jain, Morales, 2005). The doxorubicin was encapsulated into the alkyl layer of oleic acid via hydrophobic interactions. The release of doxorubicin can be controlled and the presence of doxorubicin does not interfere with the magnetization properties of IONPs. Similarly, Sahoo et al. demonstrate mono-oleate-coated, magnetic nanoparticles (GMOMNPs) can dually deliver paclitaxel and Rapamycin. With the help of the alkyl chain, $\sim 95 \%$ encapsulation efficacy and $9.5 \%$ loading efficacy was achieved by these particles. When modified with HER2 antibody as a targeting ligand, GMO-MNPs showed enhanced uptake and cell toxicity in human breast carcinoma cell line (MCF-7) (Dilnawaz et al., 2010).

Quantum dots (QDs) are made from semiconductor materials and have unique optical properties, for example, they are much brighter and more stable than organic dyes. The spectrum of QDs can be simply and accurately tuned according to their size. A very similar strategy with IONPs was taken to allow the conjugation of drugs with the NPs.

Gold NPs (AuNPs) provide promising optical contrast agents as a result of their size and optical properties (Kim et al., 2007). AuNPs with different shapes, such as nanospheres, nanocages and nanorods have been investigated as contrast agents. AuNPs are highly attractive platforms for the delivery of drugs to targeted tissues and cells. The drugs can be loaded into the AuNPs through covalent conjugation or non-covalent association (e.g. high drug loading of paclitaxel was achieved through conjugation of paclitaxel and AuNPs). Gibson et al. conjugated paclitaxel with mercaptophenol-functionalized gold nanoparticles through an oligoethylene glycol spacer using carbodiimide-based esterification chemistry (Figure 5) (Gibson, Khanal, 2007). Hwu et al. synthesized paclitaxel-PEG-thiol at the C-2 position using a degradable phosphodiester linkage and attached it to the surface of citratecapped, gold nanoparticles or maleimide-coated, magnetite nanoparticles (Hwu, Lin, 2008). The release of the drugs from the NPs is triggered by phosphodiesterases in cancer cells and there is no release of drug in the serum. Similarly, to increase the solubility of paclitaxel, Mirkin et al. attached paclitaxel-oligonucleotide-thiol conjugated on to the surface of gold nanoparticles (Lee et al., 2008a). These nanoparticles enhanced the cytotoxicity of paclitaxel in paclitaxel-sensitive and resistant cells. Additionally, the hydrophobic layer on the surface of AuNPs was utilized for the solubilization of hydrophobic drug through hydrophobic interaction by Rotello et al. (Kim et al., 2009). These methods provide a simple and versatile method for drug delivery using AuNPs and may inspire more work with other type of theranostic NPs to deliver drugs using the same strategy. 


\section{Future perspectives}

Nanomedicine has shown tremendous therapeutic potentials to treat a variety of diseases for both research and clinical applications. Several nanoparticulate formulations, such as Doxil and Abraxane, have been approved by the FDA to treat cancers and have significantly improved the safety of the drugs that are delivered. However, the efficacy of these formulations for cancer therapy has not advanced to an appropriate degree. In the past several decades, development of nano-formulations is particularly focused on the improving the stability and pharmacokinetics of drug formulation and enhancing the targeting delivery of formulations. However, abnormalities in tumor, such as growth induced solid stress, abnormal blood vessel networks, elevated interstitial fluid pressure (IFP) and dense interstitial structure, contribute to resistance to anti-cancer therapy.

Recently, many studies have shown that cancer-associated fibroblasts have significantly contributed to angiogenesis in tumor, tumor's growth, invasion and metastasis (Kalluri and Zeisberg, 2006). Stroma also increases IFP, leading to low penetration of drug in the tumor (Heldin et al., 2004). Using nanoparticulate formulation to remodel the tumor microenvironment may be a powerful strategy to sensitize tumor cells to chemotherapy. Codelivery of stromal cell inhibitor and chemo-drugs to remodel the tumor microenvironment has already shown very potent effects on the growth of tumor (Olive et al., 2009; Pietras et al., 2002).

Drug combination with synergistic effect against cancer will be another strategy to maximize the anti-cancer efficacy. Drug combination may exhibit synergistic or antagonistic effect, depending on the doses and ratio of the two drugs (Chou, 2010). To deliver drug combination at optimal ratio to the tumor, both drugs co-encapsulated in a single formulation is highly desirable. More importantly, the ratio of released drugs from single formulations need be precisely controlled at the optimal ratio. The choice of drugs for combination therapy can be difficult. It has been largely a trial-and-error attempt. Recent advances in genetic expression profiling and bioinformatics should give a rational base for the choice (Lee et al., 2012b). Co-encapsulating two or more drugs in a single delivery system can be problematic. For example, the drugs in optimal combination may differ in solubility. Formulations which can deliver multiple drugs with diverse physicochemical properties are also desired.

\section{Acknowledgments}

This work was supported by NIH grants CA129835, CA129421, CA151652, CA151455 and CA149363. We thank Kelly Racette, C.H. Michael Lin for their assistance in manuscript preparation.

\section{References}

Adams ML, Lavasanifar A, Kwon GS. Amphiphilic block copolymers for drug delivery. J Pharm Sci. 2003; 92:1343-1355. [PubMed: 12820139]

Amann LC, Gandal MJ, Lin R, Liang Y, Siegel SJ. In Vitro-In Vivo Correlations of Scalable PLGARisperidone Implants for the Treatment of Schizophrenia. Pharm Res. 2010; 27:1730-1737. [PubMed: 20422263]

Auweter H, André V, Horn D, Lüddecke E. THE FUNCTION OF GELATIN IN CONTROLLED PRECIPITATION PROCESSES OF NANOSIZE PARTICLES. J Dispersion Sci Technol. 1998; 19:163-184.

Auzenne E, Donato NJ, Li C, Leroux E, Price RE, Farquhar D, et al. Superior therapeutic profile of poly-L-glutamic acid-paclitaxel copolymer compared with taxol in xenogeneic compartmental models of human ovarian carcinoma. Clin Cancer Res. 2002; 8:573-581. [PubMed: 11839679] 
Bala I, Hariharan S, Kumar M. PLGA nanoparticles in drug delivery: the state of the art. Crit Rev Ther Drug. 2004; 21:387.

Bangham A, Horne R. Negative staining of phospholipids and their structural modification by surfaceactive agents as observed in the electron microscope. J Mol Biol. 1964; 8 660-IN10.

Barenholz Y. Doxil(R)--the first FDA-approved nano-drug: lessons learned. J Control Release. 2012; 160:117-134. [PubMed: 22484195]

Battaglia L, Serpe L, Muntoni E, Zara G, Trotta M, Gallarate M. Methotrexate-loaded SLNs prepared by coacervation technique: in vitro cytotoxicity and in vivo pharmacokinetics and biodistribution. Nanomedicine. 2011; 6:1561-1573. [PubMed: 22011315]

Bhatt R, de Vries P, Tulinsky J, Bellamy G, Baker B, Singer JW, et al. Synthesis and in vivo antitumor activity of poly (L-glutamic acid) conjugates of 20 (S)-camptothecin. J Med Chem. 2003; 46:190193. [PubMed: 12502373]

Bolling C, Graefe T, Lubbing C, Jankevicius F, Uktveris S, Cesas A, et al. Phase II study of MTXHSA in combination with cisplatin as first line treatment in patients with advanced or metastatic transitional cell carcinoma. Invest New Drugs. 2006; 24:521-527. [PubMed: 16699974]

Bruce JY, Eickhoff J, Pili R, Logan T, Carducci M, Arnott J, et al. A phase II study of 2methoxyestradiol nanocrystal colloidal dispersion alone and in combination with sunitinib malate in patients with metastatic renal cell carcinoma progressing on sunitinib malate. Invest New Drugs. 2012; 30:794-802. [PubMed: 21174224]

Bunjes H, Drechsler M, Koch MH, Westesen K. Incorporation of the model drug ubidecarenone into solid lipid nanoparticles. Pharm Res. 2001; 18:287-293. [PubMed: 11442266]

Cai S, Vijayan K, Cheng D, Lima EM, Discher DE. Micelles of different morphologies—advantages of worm-like filomicelles of PEO-PCL in paclitaxel delivery. Pharm Res. 2007; 24:2099-2109. [PubMed: 17564817]

Cartwright H. Pfizer Becomes BIND Therapeutics' Second Major Nanomedicine Collaborator. PharmaDeals Review. 20132013.

Chang EI, Galvez MG, Glotzbach JP, Hamou CD, El-ftesi S, Rappleye CT, et al. Vascular anastomosis using controlled phase transitions in poloxamer gels. Nat Med. 2011; 17:1147-1152. [PubMed: 21873986]

Chen H, Khemtong C, Yang X, Chang X, Gao J. Nanonization strategies for poorly water-soluble drugs. Drug Discovery Today. 2011; 16:354-360. [PubMed: 20206289]

Cheng J, Khin KT, Jensen GS, Liu A, Davis ME. Synthesis of linear, beta-cyclodextrin-based polymers and their camptothecin conjugates. Bioconjug Chem. 2003; 14:1007-1017. [PubMed: 13129405]

Cheng J, Teply BA, Sherifi I, Sung J, Luther G, Gu FX, et al. Formulation of functionalized PLGAPEG nanoparticles for in vivo targeted drug delivery. Biomaterials. 2007; 28:869-876. [PubMed: 17055572]

Chertok B, Moffat BA, David AE, Yu F, Bergemann C, Ross BD, et al. Iron oxide nanoparticles as a drug delivery vehicle for MRI monitored magnetic targeting of brain tumors. Biomaterials. 2008; 29:487-496. [PubMed: 17964647]

Chou T-C. Drug combination studies and their synergy quantification using the Chou-Talalay method. Cancer Res. 2010; 70:440-446. [PubMed: 20068163]

Danhauser-Riedl S, Hausmann E, Schick HD, Bender R, Dietzfelbinger H, Rastetter J, et al. Phase I clinical and pharmacokinetic trial of dextran conjugated doxorubicin (AD-70, DOX-OXD). Invest New Drugs. 1993; 11:187-195. [PubMed: 7505268]

Danson S, Ferry D, Alakhov V, Margison J, Kerr D, Jowle D, et al. Phase I dose escalation and pharmacokinetic study of pluronic polymer-bound doxorubicin (SP1049C) in patients with advanced cancer. Br J Cancer. 2004; 90:2085-2091. [PubMed: 15150584]

de Waard H, Grasmeijer N, Hinrichs WL, Eissens AC, Pfaffenbach PP, Frijlink HW. Preparation of drug nanocrystals by controlled crystallization: application of a 3-way nozzle to prevent premature crystallization for large scale production. Eur J Pharm Sci. 2009; 38:224-229. [PubMed: 19631270] 
De Waard H, Hinrichs W, Frijlink H. A novel bottom-up process to produce drug nanocrystals: controlled crystallization during freeze-drying. J Control Release. 2008; 128:179-183. [PubMed: 18423767]

Dilnawaz F, Singh A, Mohanty C, Sahoo SK. Dual drug loaded superparamagnetic iron oxide nanoparticles for targeted cancer therapy. Biomaterials. 2010; 31:3694-3706. [PubMed: 20144478]

Dromi S, Frenkel V, Luk A, Traughber B, Angstadt M, Bur M, et al. Pulsed-High Intensity Focused Ultrasound and Low Temperature-Sensitive Liposomes for Enhanced Targeted Drug Delivery and Antitumor Effect. Clin Cancer Res. 2007; 13:2722-2727. [PubMed: 17473205]

Drummond DC, Noble CO, Guo Z, Hong K, Park JW, Kirpotin DB. Development of a highly active nanoliposomal irinotecan using a novel intraliposomal stabilization strategy. Cancer Res. 2006; 66:3271-3277. [PubMed: 16540680]

Duffaud F, Borner M, Chollet P, Vermorken JB, Bloch J, Degardin M, et al. Phase II study of OSI-211 (liposomal lurtotecan) in patients with metastatic or loco-regional recurrent squamous cell carcinoma of the head and neck. An EORTC New Drug Development Group study. Eur J Cancer. 2004; 40:2748-2752. [PubMed: 15571957]

Dumortier G, Grossiord JL, Agnely F, Chaumeil JC. A review of poloxamer 407 pharmaceutical and pharmacological characteristics. Pharm Res. 2006; 23:2709-2728. [PubMed: 17096184]

Duncan R. Polymer conjugates as anticancer nanomedicines. Nat Rev Cancer. 2006; 6:688-701. [PubMed: 16900224]

Duncan R, Gac-Breton S, Keane R, Musila R, Sat Y, Satchi R, et al. Polymer-drug conjugates, PDEPT and PELT: basic principles for design and transfer from the laboratory to clinic. J Control Release. 2001; 74:135-146. [PubMed: 11489490]

Duncan R, Kopeckova-Rejmanova P, Strohalm J, Hume I, Cable HC, Pohl J, et al. Anticancer agents coupled to N-(2-hydroxypropyl)methacrylamide copolymers. I. Evaluation of daunomycin and puromycin conjugates in vitro. Br J Cancer. 1987; 55:165-174. [PubMed: 3468994]

Elzoghby AO, Samy WM, Elgindy NA. Albumin-based nanoparticles as potential controlled release drug delivery systems. J Control Release. 2012; 157:168-182. [PubMed: 21839127]

Emerich DF, Thanos CG. Targeted nanoparticle-based drug delivery and diagnosis. J Drug Target. 2007; 15:163-183. [PubMed: 17454354]

Emerson DL, Bendele R, Brown E, Chiang S, Desjardins JP, Dihel LC, et al. Antitumor efficacy, pharmacokinetics, and biodistribution of NX 211: a low-clearance liposomal formulation of lurtotecan. Clin Cancer Res. 2000; 6:2903-2912. [PubMed: 10914740]

Ernsting MJ, Murakami M, Undzys E, Aman A, Press B, Li SD. A docetaxel-carboxymethylcellulose nanoparticle outperforms the approved taxane nanoformulation, Abraxane, in mouse tumor models with significant control of metastases. J Control Release. 2012a; 162:575-581. [PubMed: 22967490]

Ernsting MJ, Tang WL, MacCallum NW, Li SD. Preclinical pharmacokinetic, biodistribution, and anti-cancer efficacy studies of a docetaxel-carboxymethylcellulose nanoparticle in mouse models. Biomaterials. 2012b; 33:1445-1454. [PubMed: 22079003]

Esmaeili F, Ghahremani MH, Esmaeili B, Khoshayand MR, Atyabi F, Dinarvand R. PLGA nanoparticles of different surface properties: Preparation and evaluation of their body distribution. Int J Pharm. 2008; 349:249-255. [PubMed: 17875373]

Faisant N, Siepmann J, Benoit J. PLGA-based microparticles: elucidation of mechanisms and a new, simple mathematical model quantifying drug release. Eur J Pharm Sci. 2002; 15:355-366. [PubMed: 11988397]

Fang J, Nakamura H, Maeda H. The EPR effect: Unique features of tumor blood vessels for drug delivery, factors involved, and limitations and augmentation of the effect. Adv Drug Deliv Rev. 2011; 63:136-151. [PubMed: 20441782]

Fassas A, Anagnostopoulos A. The use of liposomal daunorubicin (DaunoXome) in acute myeloid leukemia. Leuk Lymphoma. 2005; 46:795-802. [PubMed: 16019523]

Ferrari M. Cancer nanotechnology: opportunities and challenges. Nat Rev Cancer. 2005; 5:161-171. [PubMed: 15738981] 
Fonseca C, Simoes S, Gaspar R. Paclitaxel-loaded PLGA nanoparticles: preparation, physicochemical characterization and in vitro anti-tumoral activity. J Control Release. 2002; 83:273-286. [PubMed: 12363453]

Fritze A, Hens F, Kimpfler A, Schubert R, Peschka-Süss R. Remote loading of doxorubicin into liposomes driven by a transmembrane phosphate gradient. Biochim Biophys Acta Biomembr. 2006; 1758:1633-1640.

Gabizon A, Shmeeda H, Barenholz Y. Pharmacokinetics of pegylated liposomal doxorubicin. Clin pharmacokinet. 2003; 42:419-436. [PubMed: 12739982]

Gao L, Zhang D, Chen M. Drug nanocrystals for the formulation of poorly soluble drugs and its application as a potential drug delivery system. J Nanopart Res. 2008; 10:845-862.

Gibson JD, Khanal BP, Zubarev ER. Paclitaxel-functionalized gold nanoparticles. J Am Chem Soc. 2007; 129:11653-11661. [PubMed: 17718495]

Green M, Manikhas G, Orlov S, Afanasyev B, Makhson A, Bhar P, et al. Abraxane ${ }^{\circledR}$, a novel Cremophor ${ }^{\circledR}$-free, albumin-bound particle form of paclitaxel for the treatment of advanced nonsmall-cell lung cancer. Ann Oncol. 2006; 17:1263-1268. [PubMed: 16740598]

Guo S, Huang L. Nanoparticles escaping RES and endosome: challenges for siRNA delivery for cancer therapy. J Nanomater. 2011; 2011:11.

Hamaguchi T, Kato K, Yasui H, Morizane C, Ikeda M, Ueno H, et al. A phase I and pharmacokinetic study of NK105, a paclitaxel-incorporating micellar nanoparticle formulation. Br J Cancer. 2007; 97:170-176. [PubMed: 17595665]

Hartung G, Stehle G, Sinn H, Wunder A, Schrenk HH, Heeger S, et al. Phase I trial of methotrexatealbumin in a weekly intravenous bolus regimen in cancer patients. Clin Cancer Res. 1999; 5:753759. [PubMed: 10213209]

Heldin C-H, Rubin K, Pietras K, Östman A. High interstitial fluid pressure - an obstacle in cancer therapy. Nat Rev Cancer. 2004; 4:806-813. [PubMed: 15510161]

Homsi J, Simon GR, Garrett CR, Springett G, De Conti R, Chiappori AA, et al. Phase I trial of poly-Lglutamate camptothecin (CT-2106) administered weekly in patients with advanced solid malignancies. Clin Cancer Res. 2007; 13:5855-5861. [PubMed: 17908979]

Hrkach J, Von Hoff D, Ali MM, Andrianova E, Auer J, Campbell T, et al. Preclinical development and clinical translation of a PSMA-targeted docetaxel nanoparticle with a differentiated pharmacological profile. Sci Transl Med. 2012; 4 128ra39-ra39.

Huang L, Liu Y. In vivo delivery of RNAi with lipid-based nanoparticles. Annu Rev Biomed Eng. 2011; 13:507-530. [PubMed: 21639780]

Hwu JR, Lin YS, Josephrajan T, Hsu M-H, Cheng F-Y, Yeh C-S, et al. Targeted paclitaxel by conjugation to iron oxide and gold nanoparticles. J Am Chem Soc. 2008; 131:66-68. [PubMed: 19072111]

Jain RA. The manufacturing techniques of various drug loaded biodegradable poly (lactide- $<\mathrm{i}>\operatorname{co}</$ i>-glycolide)(PLGA) devices. Biomaterials. 2000; 21:2475-2490. [PubMed: 11055295]

Jain TK, Morales MA, Sahoo SK, Leslie-Pelecky DL, Labhasetwar V. Iron oxide nanoparticles for sustained delivery of anticancer agents. Mol Pharm. 2005; 2:194-205. [PubMed: 15934780]

Junghanns J-UA, Müller RH. Nanocrystal technology, drug delivery and clinical applications. Int J Nanomedicine. 2008; 3:295. [PubMed: 18990939]

Kalluri R, Zeisberg M. Fibroblasts in cancer. Nat Rev Cancer. 2006; 6:392-401. [PubMed: 16572188]

Keck CM, Müller RH. Drug nanocrystals of poorly soluble drugs produced by high pressure homogenisation. Eur J Pharm Biopharm. 2006; 62:3-16. [PubMed: 16129588]

Kim CK, Ghosh P, Pagliuca C, Zhu Z-J, Menichetti S, Rotello VM. Entrapment of hydrophobic drugs in nanoparticle monolayers with efficient release into cancer cells. J Am Chem Soc. 2009; 131:1360-1361. [PubMed: 19133720]

Kim D, Park S, Lee JH, Jeong YY, Jon S. Antibiofouling polymer-coated gold nanoparticles as a contrast agent for in vivo X-ray computed tomography imaging. J Am Chem Soc. 2007; 129:7661-7665. [PubMed: 17530850]

Klibanov AL, Maruyama K, Torchilin VP, Huang L. Amphipathic polyethyleneglycols effectively prolong the circulation time of liposomes. FEBS Lett. 1990; 268:235-237. [PubMed: 2384160] 
Ko AH, Tempero MA, Shan YS, Su WC, Lin YL, Dito E, et al. A multinational phase 2 study of nanoliposomal irinotecan sucrosofate (PEP02, MM-398) for patients with gemcitabine-refractory metastatic pancreatic cancer. Br J Cancer. 2013; 109:920-925. [PubMed: 23880820]

Kohler N, Sun C, Wang J, Zhang M. Methotrexate-modified superparamagnetic nanoparticles and their intracellular uptake into human cancer cells. Langmuir. 2005; 21:8858-8864. [PubMed: 16142971]

Kojima T, Hashida M, Muranishi S, Sezaki H. Mitomycin C-dextran conjugate: a novel high molecular weight pro-drug of mitomycin C. J Pharm Pharmacol. 1980; 32:30-34. [PubMed: 6102123]

Kopeček J, Kopečková P, Minko T, Lu Z-R. HPMA copolymer-anticancer drug conjugates: design, activity, and mechanism of action. Eur J Pharm Biopharm. 2000; 50:61-81. [PubMed: 10840193]

Koudelka S, Turanek J. Liposomal paclitaxel formulations. J Control Release. 2012; 163:322-334. [PubMed: 22989535]

Kratz F. Albumin as a drug carrier: design of prodrugs, drug conjugates and nanoparticles. J Control Release. 2008; 132:171-183. [PubMed: 18582981]

Kulke MH, Chan JA, Meyerhardt JA, Zhu AX, Abrams TA, Blaszkowsky LS, et al. A prospective phase II study of 2-methoxyestradiol administered in combination with bevacizumab in patients with metastatic carcinoid tumors. Cancer Chemother Pharmacol. 2011; 68:293-300. [PubMed: 20960192]

Kumari A, Yadav SK, Yadav SC. Biodegradable polymeric nanoparticles based drug delivery systems. Colloid Surface B. 2010; 75:1-18.

Lalatsa A, Schätzlein AG, Mazza M, Le TBH, Uchegbu IF. Amphiphilic Poly (L-amino acids)-New materials for drug delivery. J Control Release. 2012

Lee J-L, Ahn J-H, Park SH, Lim HY, Kwon JH, Ahn S, et al. Phase II study of a cremophor-free, polymeric micelle formulation of paclitaxel for patients with advanced urothelial cancer previously treated with gemcitabine and platinum. Invest New Drugs. 2012a; 30:1984-1990. [PubMed: 22012004]

Lee J-S, Seferos DS, Giljohann DA, Mirkin CA. Thermodynamically controlled separation of polyvalent 2-nm gold nanoparticle-oligonucleotide conjugates. J Am Chem Soc. 2008a; 130:54305431. [PubMed: 18370386]

Lee KS, Chung HC, Im SA, Park YH, Kim CS, Kim S-B, et al. Multicenter phase II trial of GenexolPM, a Cremophor-free, polymeric micelle formulation of paclitaxel, in patients with metastatic breast cancer. Breast Cancer Res Treat. 2008b; 108:241-250. [PubMed: 17476588]

Lee MJ, Ye AS, Gardino AK, Heijink AM, Sorger PK, MacBeath G, et al. Sequential application of anticancer drugs enhances cell death by rewiring apoptotic signaling networks. Cell. 2012b; 149:780-794. [PubMed: 22579283]

Leonard RC, Williams S, Tulpule A, Levine AM, Oliveros S. Improving the therapeutic index of anthracycline chemotherapy: focus on liposomal doxorubicin (Myocet). Breast. 2009; 18:218-224. [PubMed: 19656681]

Li C. Poly (L-glutamic acid)-anticancer drug conjugates. Adv Drug Deliv Rev. 2002; 54:695-713. [PubMed: 12204599]

Li C, Wallace S. Polymer-drug conjugates: recent development in clinical oncology. Adv Drug Deliv Rev. 2008; 60:886-898. [PubMed: 18374448]

Li C, Yu D-F, Newman RA, Cabral F, Stephens LC, Hunter N, et al. Complete regression of wellestablished tumors using a novel water-soluble poly (L-glutamic acid)-paclitaxel conjugate. Cancer Res. 1998; 58:2404-2409. [PubMed: 9622081]

Li J, Chen Y-C, Tseng Y-C, Mozumdar S, Huang L. Biodegradable calcium phosphate nanoparticle with lipid coating for systemic siRNA delivery. J Control Release. 2010; 142:416-421. [PubMed: 19919845]

Li J, Stayshich RM, Meyer TY. Exploiting sequence to control the hydrolysis behavior of biodegradable PLGA copolymers. J Am Chem Soc. 2011; 133:6910-6913. [PubMed: 21488683]

Li J, Yang Y, Huang L. Calcium phosphate nanoparticles with an asymmetric lipid bilayer coating for siRNA delivery to the tumor. J Control Release. 2012; 158:108-114. [PubMed: 22056915] 
Li S-D, Huang L. Nanoparticles evading the reticuloendothelial system: role of the supported bilayer. Biochim Biophys Acta Biomembr. 2009; 1788:2259-2266.

Lim W, Tan E, Toh C, Hee S, Leong S, Ang P, et al. Phase I pharmacokinetic study of a weekly liposomal paclitaxel formulation (Genexol®-PM) in patients with solid tumors. Ann Oncol. 2010; 21:382-388. [PubMed: 19633055]

Lin NU, Parker LM, Come SE, Burstein HJ, Haldoupis M, Ryabin N, et al. Phase II study of CT-2103 as first-or second-line chemotherapy in patients with metastatic breast cancer: unexpected incidence of hypersensitivity reactions. Invest New Drugs. 2007; 25:369-375. [PubMed: 17345004]

Liu J, Xiao Y, Allen C. Polymer-drug compatibility: a guide to the development of delivery systems for the anticancer agent, ellipticine. J Pharm Sci. 2004; 93:132-143. [PubMed: 14648643]

Liversidge GG, Cundy KC. Particle size reduction for improvement of oral bioavailability of hydrophobic drugs: I. Absolute oral bioavailability of nanocrystalline danazol in beagle dogs. Int $\mathbf{J}$ Pharm. 1995; 125:91-97.

Liversidge GG, Cundy KC, Bishop JF, Czekai DA. Surface modified drug nanoparticles. Google Patents. 1992

Maeda H, Wu J, Sawa T, Matsumura Y, Hori K. Tumor vascular permeability and the EPR effect in macromolecular therapeutics: a review. J Control Release. 2000; 65:271-284. [PubMed: 10699287]

Makadia HK, Siegel SJ. Poly lactic-co-glycolic acid (PLGA) as biodegradable controlled drug delivery carrier. Polymers. 2011; 3:1377-1397. [PubMed: 22577513]

May JP, Li SD. Hyperthermia-induced drug targeting. Expert Opin Drug Deliv. 2013; 10:511-527. [PubMed: 23289519]

Mehnert W, Mäder K. Solid lipid nanoparticles: production, characterization and applications. Adv Drug Deliv Rev. 2001; 47:165-196. [PubMed: 11311991]

Micha JP, Goldstein BH, Birk CL, Rettenmaier MA, Brown JV III. Abraxane in the treatment of ovarian cancer: the absence of hypersensitivity reactions. Gynecol Oncol. 2006; 100:437-438. [PubMed: 16226797]

Miele E, Spinelli GP, Miele E, Tomao F, Tomao S. Albumin-bound formulation of paclitaxel (Abraxane ${ }^{\circ}$ ABI-007) in the treatment of breast cancer. Int J Nanomedicine. 2009; 4:99. [PubMed: 19516888]

Miller SM, Wang AZ. Nanomedicine in chemoradiation. Ther Deliv. 2013; 4:239-250. [PubMed: 23343162]

Mitra S, Gaur U, Ghosh P, Maitra A. Tumour targeted delivery of encapsulated dextran-doxorubicin conjugate using chitosan nanoparticles as carrier. J Control Release. 2001; 74:317-323. [PubMed: 11489513]

Muddana HS, Morgan TT, Adair JH, Butler PJ. Photophysics of Cy3-encapsulated calcium phosphate nanoparticles. Nano Lett. 2009; 9:1559-1566. [PubMed: 19260707]

Muller RH, Keck CM. Challenges and solutions for the delivery of biotech drugs-a review of drug nanocrystal technology and lipid nanoparticles. J Biotechnol. 2004; 113:151-170. [PubMed: 15380654]

Müller RH, Mäder K, Gohla S. Solid lipid nanoparticles (SLN) for controlled drug delivery-a review of the state of the art. Eur J Pharm Biopharm. 2000; 50:161-177. [PubMed: 10840199]

Murakami M, Ernsting MJ, Undzys E, Holwell N, Foltz WD, Li SD. Docetaxel Conjugate Nanoparticles That Target alpha-Smooth Muscle Actin-Expressing Stromal Cells Suppress Breast Cancer Metastasis. Cancer Res. 2013; 73:4862-4871. [PubMed: 23907638]

Negishi T, Koizumi F, Uchino H, Kuroda J, Kawaguchi T, Naito S, et al. NK105, a paclitaxelincorporating micellar nanoparticle, is a more potent radiosensitising agent compared to free paclitaxel. Br J Cancer. 2006; 95:601-606. [PubMed: 16909136]

Neuzillet C, Tijeras-Raballand A, Cros J, Faivre S, Hammel P, Raymond E. Stromal expression of SPARC in pancreatic adenocarcinoma. Cancer Metastasis Rev. 2013

Noyes AA, Whitney WR. THE RATE OF SOLUTION OF SOLID SUBSTANCES IN THEIR OWN SOLUTIONS. J Am Chem Soc. 1897; 19:930-934. 
O'Brien ME, Socinski MA, Popovich AY, Bondarenko IN, Tomova A, Bilynsky BT, et al. Randomized phase III trial comparing single-agent paclitaxel Poliglumex (CT-2103, PPX) with single-agent gemcitabine or vinorelbine for the treatment of PS 2 patients with chemotherapynaive advanced non-small cell lung cancer. J Thorac Oncol. 2008; 3:728-734. [PubMed: 18594318]

Olive KP, Jacobetz MA, Davidson CJ, Gopinathan A, McIntyre D, Honess D, et al. Inhibition of Hedgehog signaling enhances delivery of chemotherapy in a mouse model of pancreatic cancer. Science. 2009; 324:1457-1461. [PubMed: 19460966]

Panyam J, Labhasetwar V. Biodegradable nanoparticles for drug and gene delivery to cells and tissue. Adv Drug Deliv Rev. 2003; 55:329-347. [PubMed: 12628320]

Park EK, Kim SY, Lee SB, Lee YM. Folate-conjugated methoxy poly (ethylene glycol)/poly ( $\varepsilon$ caprolactone) amphiphilic block copolymeric micelles for tumor-targeted drug delivery. $\mathrm{J}$ Control Release. 2005; 109:158-168. [PubMed: 16263189]

Peng X-H, Qian X, Mao H, Wang AY. Targeted magnetic iron oxide nanoparticles for tumor imaging and therapy. Int J Nanomedicine. 2008; 3:311. [PubMed: 18990940]

Pietras K, Rubin K, Sjoblom T, Buchdunger E, Sjoquist M, Heldin CH, et al. Inhibition of PDGF receptor signaling in tumor stroma enhances antitumor effect of chemotherapy. Cancer Res. 2002; 62:5476-5484. [PubMed: 12359756]

Prabhakar U, Blakey DC, Maeda H, Jain RK, Sevick-Muraca EM, Zamboni W, et al. Challenges and key considerations of the enhanced permeability and retention effect (EPR) for nanomedicine drug delivery in oncology. Cancer Res. 2013

Ramchandani M, Robinson D. In vitro and in vivo release of ciprofloxacin from PLGA 50: 50 implants. J Control Release. 1998; 54:167-175. [PubMed: 9724903]

Rösler A, Vandermeulen GW, Klok H-A. Advanced drug delivery devices via self-assembly of amphiphilic block copolymers. Adv Drug Deliv Rev. 2001; 53:95-108. [PubMed: 11733119]

Ross H, Bonomi P, Langer C, O’Brien M, O’Byrne K, Paz-Ares L, et al. Effect of gender on outcome in two randomized phase III trials of paclitaxel poliglumex (PPX) in chemonaïve pts with advanced NSCLC and poor performance status (PS2). J Clin Oncol (Meeting Abstracts). 2006:7039.

Roy AC, Park SR, Cunningham D, Kang YK, Chao Y, Chen LT, et al. A randomized phase II study of PEP02 (MM-398), irinotecan or docetaxel as a second-line therapy in patients with locally advanced or metastatic gastric or gastro-oesophageal junction adenocarcinoma. Ann Oncol. 2013; 24:1567-1573. [PubMed: 23406728]

Sabbatini P, Aghajanian C, Dizon D, Anderson S, Dupont J, Brown JV, et al. Phase II study of CT-2103 in patients with recurrent epithelial ovarian, fallopian tube, or primary peritoneal carcinoma. J Clin Oncol. 2004; 22:4523-4531. [PubMed: 15542803]

Sahoo SK, Labhasetwar V. Nanotech approaches to drug delivery and imaging. Drug Discovery Today. 2003; 8:1112-1120. [PubMed: 14678737]

Saito G, Swanson JA, Lee K-D. Drug delivery strategy utilizing conjugation via reversible disulfide linkages: role and site of cellular reducing activities. Adv Drug Deliv Rev. 2003; 55:199-215. [PubMed: 12564977]

Schluep T, Cheng J, Khin KT, Davis ME. Pharmacokinetics and biodistribution of the camptothecinpolymer conjugate IT-101 in rats and tumor-bearing mice. Cancer Chemother Pharmacol. 2006a; 57:654-662. [PubMed: 16133526]

Schluep T, Hwang J, Cheng J, Heidel JD, Bartlett DW, Hollister B, et al. Preclinical efficacy of the camptothecin-polymer conjugate IT-101 in multiple cancer models. Clin Cancer Res. 2006b; 12:1606-1614. [PubMed: 16533788]

Schluep T, Hwang J, Hildebrandt IJ, Czernin J, Choi CH, Alabi CA, et al. Pharmacokinetics and tumor dynamics of the nanoparticle IT-101 from PET imaging and tumor histological measurements. Proc Natl Acad Sci USA. 2009; 106:11394-11399. [PubMed: 19564622]

Schmolka IR. Poloxamers in the pharmaceutical industry: CRC Press, Boca Raton, FL. 1991

Scholer N, Krause K, Kayser O, Muller RH, Borner K, Hahn H, et al. Atovaquone nanosuspensions show excellent therapeutic effect in a new murine model of reactivated toxoplasmosis. Antimicrob Agents Chemother. 2001; 45:1771-1779. [PubMed: 11353624] 
Seiden MV, Muggia F, Astrow A, Matulonis U, Campos S, Roche M, et al. A phase II study of liposomal lurtotecan (OSI-211) in patients with topotecan resistant ovarian cancer. Gynecol Oncol. 2004; 93:229-232. [PubMed: 15047241]

Seymour LW, Ferry DR, Kerr DJ, Rea D, Whitlock M, Poyner R, et al. Phase II studies of polymerdoxorubicin (PK1, FCE28068) in the treatment of breast, lung and colorectal cancer. Int J Oncol. 2009; 34:1629-1636. [PubMed: 19424581]

Shegokar R, Muller RH. Nanocrystals: industrially feasible multifunctional formulation technology for poorly soluble actives. Int J Pharm. 2010; 399:129-139. [PubMed: 20674732]

Shi J, Votruba AR, Farokhzad OC, Langer R. Nanotechnology in drug delivery and tissue engineering: from discovery to applications. Nano Lett. 2010; 10:3223-3230. [PubMed: 20726522]

Singer, JW.; Baker, B.; de Vries, P.; Kumar, A.; Shaffer, S.; Vawter, E., et al. Adv Exp Med Biol. Springer; 2004. Poly-(1)-glutamic acid-paclitaxel (CT-2103)[XYOTAX ${ }^{\mathrm{TM}}$ ], a biodegradable polymeric drug conjugate; p. 81-99.

Smith A. Evaluation of poly (lactic acid) as a biodegradable drug delivery system for parenteral administration. Int J Pharm. 1986; 30:215-220.

Soppimath KS, Aminabhavi TM, Kulkarni AR, Rudzinski WE. Biodegradable polymeric nanoparticles as drug delivery devices. J Control Release. 2001; 70:1-20. [PubMed: 11166403]

Straubinger RM, Balasubramanian SV. Preparation and characterization of taxane-containing liposomes. Methods Enzymol. 2005; 391:97-117. [PubMed: 15721376]

Sun B, Yeo Y. Nanocrystals for the parenteral delivery of poorly water-soluble drugs. Curr Opin Solid State Mater Sci. 2012; 16:295-301. [PubMed: 23645994]

Sun C, Lee JS, Zhang M. Magnetic nanoparticles in MR imaging and drug delivery. Adv Drug Deliv Rev. 2008; 60:1252-1265. [PubMed: 18558452]

Svenson S. Clinical translation of nanomedicines. Curr Opin Solid State Mater Sci. 2012

Svenson S, Wolfgang M, Hwang J, Ryan J, Eliasof S. Preclinical to clinical development of the novel camptothecin nanopharmaceutical CRLX101. J Control Release. 2011; 153:49-55. [PubMed: 21406204]

Swathi G, Prasanthi N, Manikiran S, Ramarao N. Solid lipid nanoparticles: colloidal carrier systems for drug delivery. ChemInform. 2012; 43 no.

Tagami T, May JP, Ernsting MJ, Li SD. A thermosensitive liposome prepared with a $\mathrm{Cu}(2)(+)$ gradient demonstrates improved pharmacokinetics, drug delivery and antitumor efficacy. J Control Release. 2012; 161:142-149. [PubMed: 22504351]

Tevaarwerk AJ, Holen KD, Alberti DB, Sidor C, Arnott J, Quon C, et al. Phase I trial of 2methoxyestradiol NanoCrystal dispersion in advanced solid malignancies. Clin Cancer Res. 2009; 15:1460-1465. [PubMed: 19228747]

Tziomalos K, Athyros VG. Fenofibrate: a novel formulation (Triglide ${ }^{\mathrm{TM}}$ ) in the treatment of lipid disorders: a review. Int J Nanomedicine. 2006; 1:129. [PubMed: 17722529]

Valle JW, Armstrong A, Newman C, Alakhov V, Pietrzynski G, Brewer J, et al. A phase 2 study of SP1049C, doxorubicin in P-glycoprotein-targeting pluronics, in patients with advanced adenocarcinoma of the esophagus and gastroesophageal junction. Invest New Drugs. 2011; 29:1029-1037. [PubMed: 20179989]

Vauthier C, Bouchemal K. Methods for the preparation and manufacture of polymeric nanoparticles. Pharm Res. 2009; 26:1025-1058. [PubMed: 19107579]

Veltkamp SA, Witteveen EO, Capriati A, Crea A, Animati F, Voogel-Fuchs M, et al. Clinical and pharmacologic study of the novel prodrug delimotecan (MEN 4901/T-0128) in patients with solid tumors. Clin Cancer Res. 2008; 14:7535-7544. [PubMed: 19010872]

Vis A, Van Der Gaast A, Van Rhijn B, Catsburg T, Schmidt C, Mickisch G. A phase II trial of methotrexate-human serum albumin (MTX-HSA) in patients with metastatic renal cell carcinoma who progressed under immunotherapy. Cancer Chemother Pharmacol. 2002; 49:342-345. [PubMed: 11914915]

Von Hoff D, Ervin TJ, Arena FP, Chiorean EG, Infante JR, Moore MJ, et al. Randomized phase III study of weekly nab-paclitaxel plus gemcitabine versus gemcitabine alone in patients with metastatic adenocarcinoma of the pancreas (MPACT). 2013 ASCO Gastrointestinal Cancers Symposium, abstract. 2012:24-26. 
Von Hoff DD, Ramanathan RK, Borad MJ, Laheru DA, Smith LS, Wood TE, et al. Gemcitabine plus nab-paclitaxel is an active regimen in patients with advanced pancreatic cancer: a phase I/II trial. J Clin Oncol. 2011; 29:4548-4554. [PubMed: 21969517]

Wang AZ, Langer R, Farokhzad OC. Nanoparticle delivery of cancer drugs. Annu Rev Med. 2012; 63:185-198. [PubMed: 21888516]

Wang Y, Grayson SM. Approaches for the preparation of non-linear amphiphilic polymers and their applications to drug delivery. Adv Drug Deliv Rev. 2012; 64:852-865. [PubMed: 22465560]

Warnecke A, Fichtner I, Sa $\beta$ G, Kratz F. Synthesis, Cleavage Profile, and Antitumor Efficacy of an Albumin-Binding Prodrug of Methotrexate that is Cleaved by Plasmin and Cathepsin B. Arch Pharm. 2007; 340:389-395.

Xiong X-B, Falamarzian A, Garg SM, Lavasanifar A. Engineering of amphiphilic block copolymers for polymeric micellar drug and gene delivery. J Control Release. 2011; 155:248-261. [PubMed: 21621570]

Xu ZP, Zeng QH, Lu GQ, Yu AB. Inorganic nanoparticles as carriers for efficient cellular delivery. Chem Eng Sci. 2006; 61:1027-1040.

Yang Y, Li J, Liu F, Huang L. Systemic delivery of siRNA via LCP nanoparticle efficiently inhibits lung metastasis. Mol Ther. 2011; 20:609-615. [PubMed: 22186791]

Zhang Y, Kim WY, Huang L. Systemic delivery of gemcitabine triphosphate via LCP nanoparticles for NSCLC and pancreatic cancer therapy. Biomaterials. 2013; 34:3447-3458. [PubMed: 23380359] 

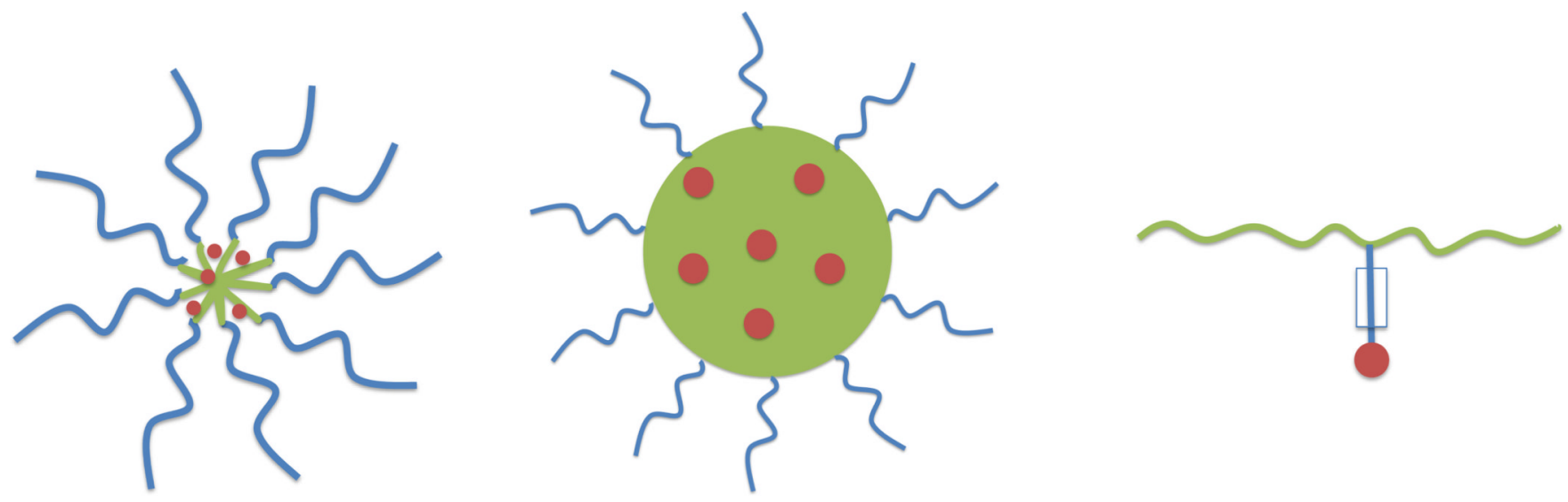

Figure 1.

The structure of polymeric micelles, polymeric nanoparticles, and polymer-drug conjugates. 


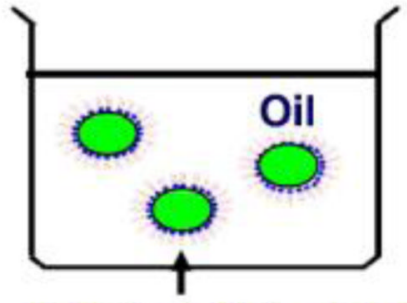

$\mathrm{HPO}_{4}{ }^{2-}(\mathrm{pH} 9)$ with DOPA

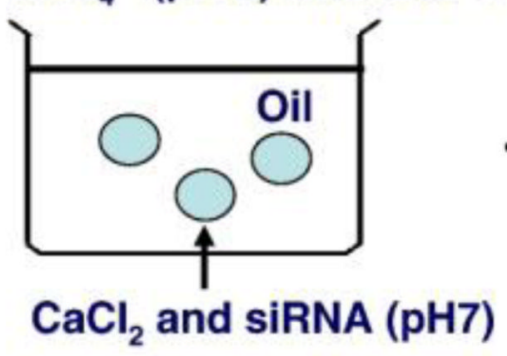

Centrifuge

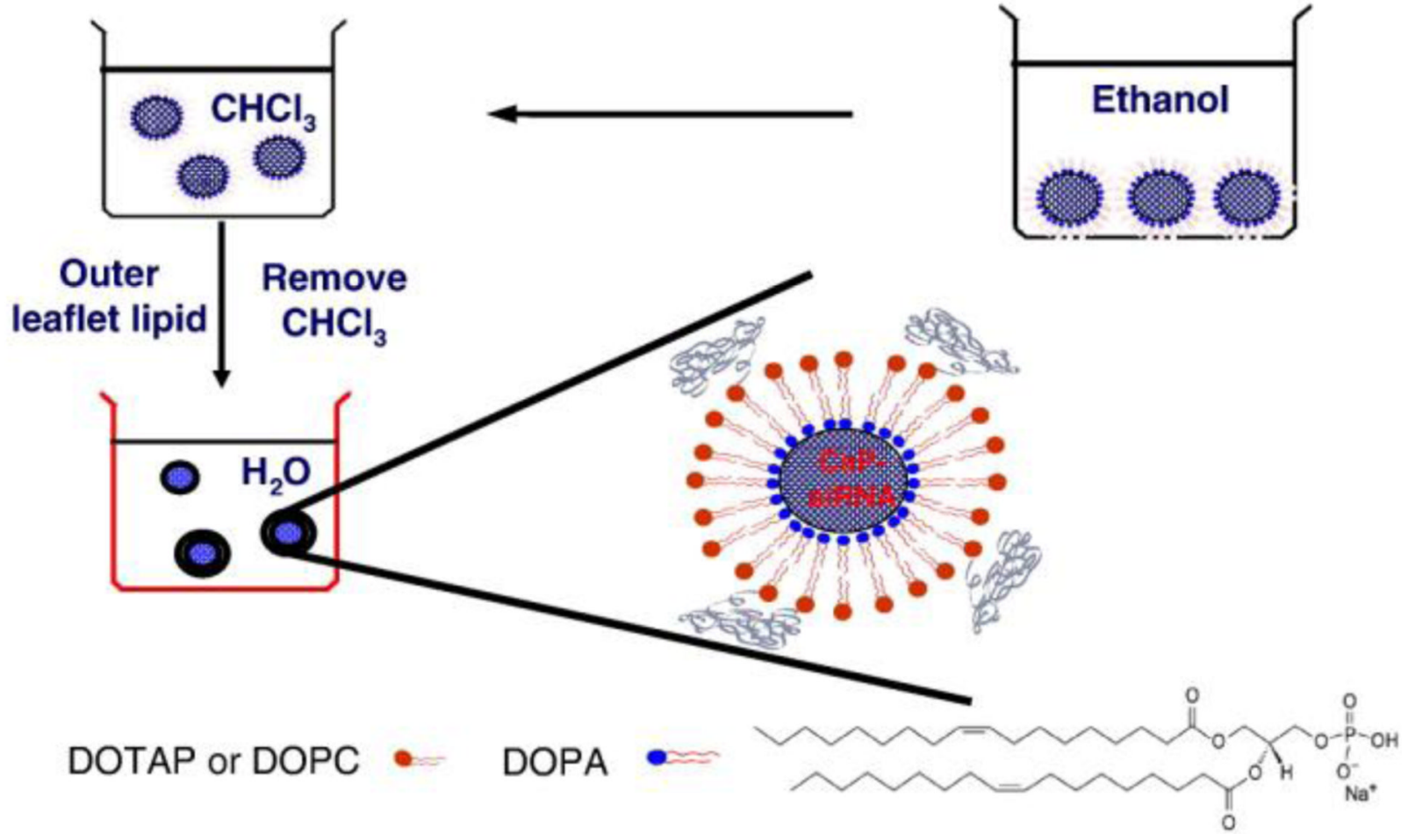

Figure 2.

Preparation of lipid/calcium/phosphate (LCP) nanoparticles. Soluble calcium ion and siRNA are mixed and distributed in one emulsion. Dioleoylphosphatydic acid (DOPA) and Phosphate salt $(\mathrm{pH}=9.0)$ is distributed in another counter emulsion. SiRNA will be encapsulated into calcium phosphate $(\mathrm{CaP})$ cores when two emulsions are combined. The DOPA stabilized $\mathrm{CaP}$ cores are further hydrated using another layer of outer leaflet lipid. Reproduced with permission from reference (Li et al., 2012). Copyright 2012 Elsevier. 
<smiles>CCNCCN(CC)CC</smiles>

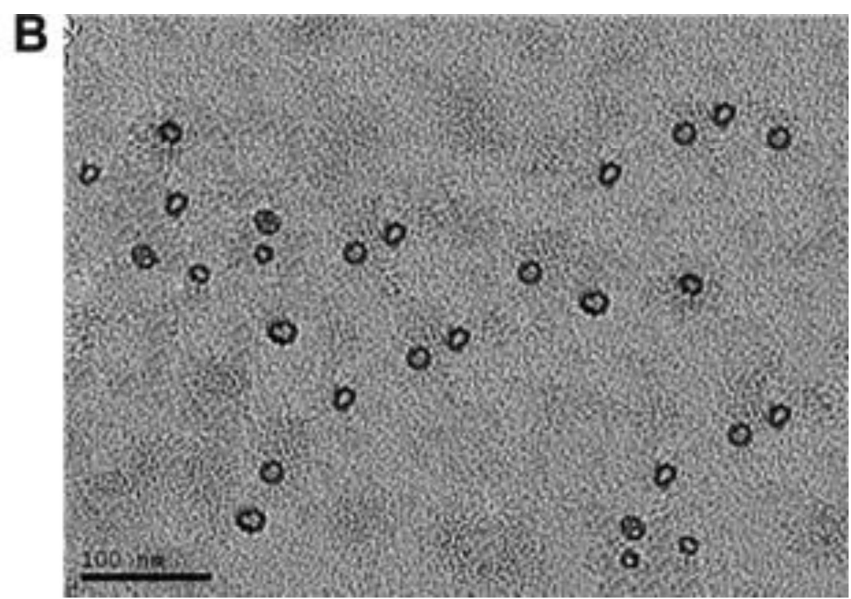

Figure 3.

Gemcitabine triphosphate, gemcitabine bioactive form, was encapsulated into Lipid/ Calcium/Phosphate nanoparticle (LCP) prepared in microemulsion. More chemo drugs with phosphate group(s) could be entrapped into LCPs and delivered systemically using this technology. (A) The chemical structure of GTP (Gemcitabine triphosphate tris(triethylammonium) salt) used in this study. (B) TEM image of GTP-loaded LCPs. Reproduced with permission from reference (Zhang, Kim, 2013). Copyright 2013 Elsevier. 


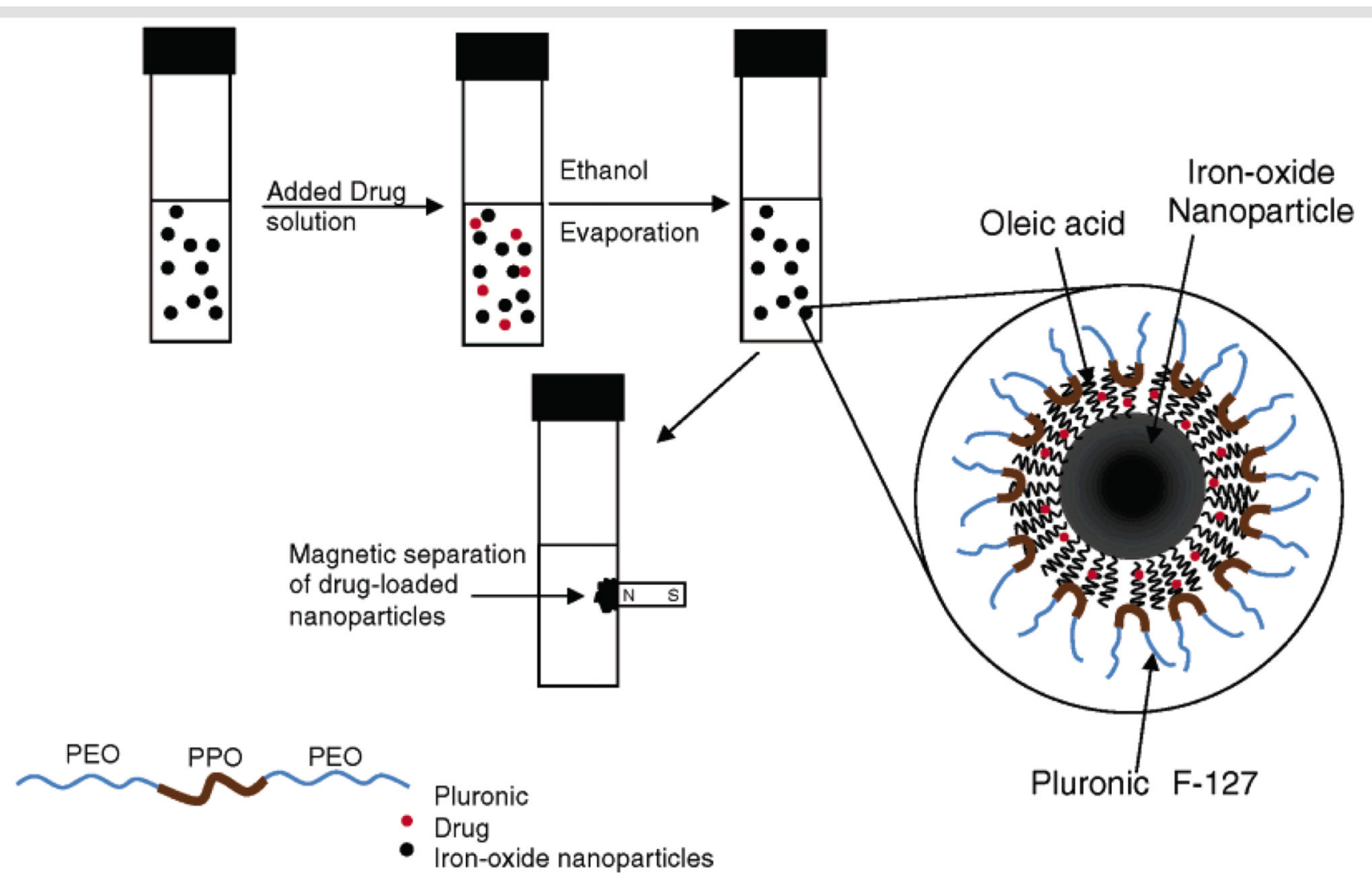

Figure 4.

Schematic representation of the formulation of iron oxide nanoparticles and the process of drug loading. Reproduced with permission from reference (Jain et al., 2005). Copyright 2005 American Chemical Society. 

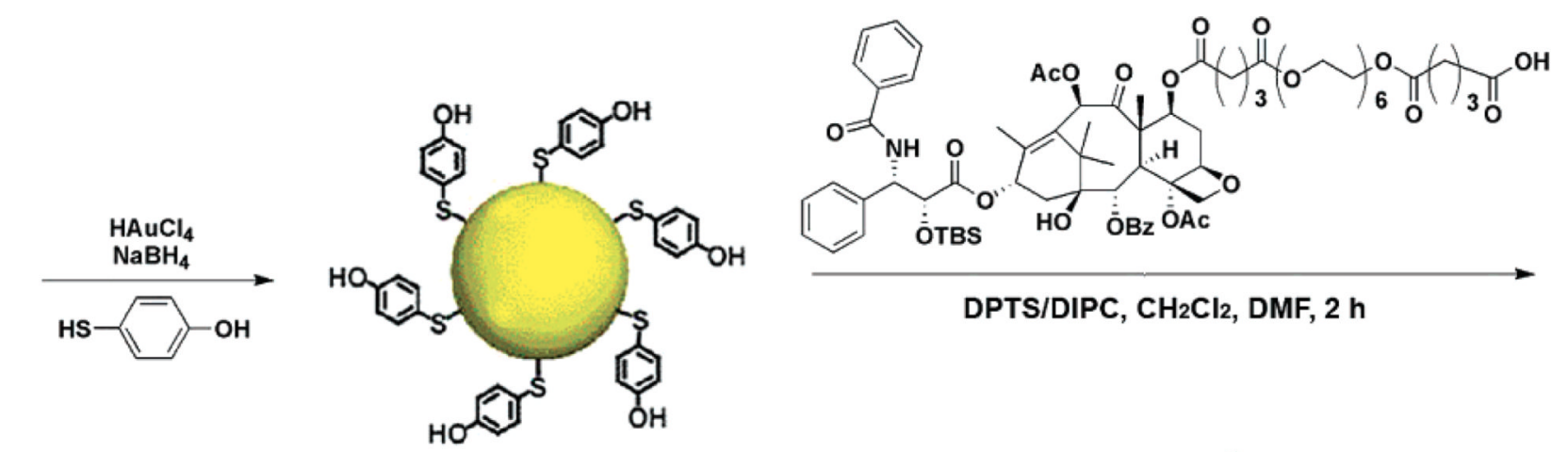

DPTS/DIPC, $\mathrm{CH}_{2} \mathrm{Cl} 2$, DMF, $2 \mathrm{~h}$

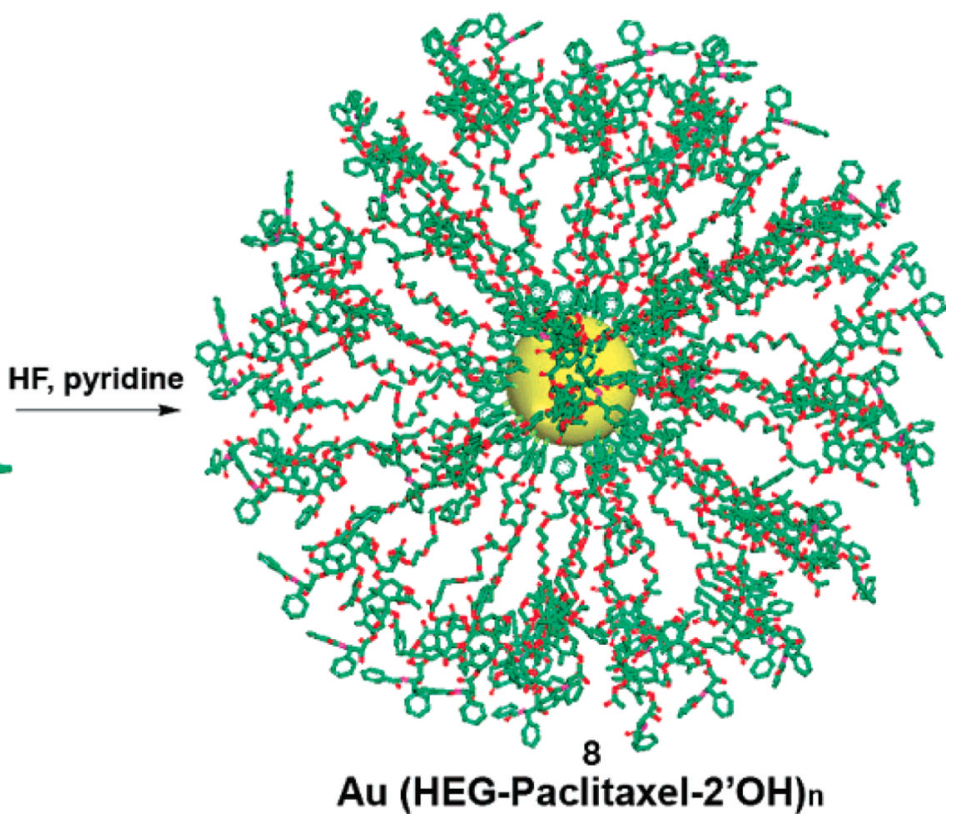

Figure 5.

Covalent coupling of paclitaxel to 4-mercaptophenol-modified $2 \mathrm{~nm}$ gold nanoparticles.

Reproduced with permission from reference (Gibson et al., 2007). Copyright 2007 American Chemical Society. 
Table 1

Fabrication methods, advantages and disadvantages of different nanoparticulate fomulations.

\begin{tabular}{|c|c|c|c|}
\hline & $\begin{array}{l}\text { Fabrication } \\
\text { techniques }\end{array}$ & Advantages & Disadvantages \\
\hline $\begin{array}{l}\text { Polymeric } \\
\text { nanoparticles }\end{array}$ & $\begin{array}{l}\text { Self-assembly; } \\
\text { nanoprecipitation; } \\
\text { emulsion-solvent } \\
\text { evaporation }\end{array}$ & $\begin{array}{l}\text { Excellent blood stability; } \\
\text { suitability for intravenous } \\
\text { injection; EPR dependant } \\
\text { tumor accumulation;; } \\
\text { controlled release; } \\
\text { multifunctional design }\end{array}$ & $\begin{array}{l}\text { Limited number of } \\
\text { polymers for } \\
\text { clinical use; } \\
\text { concerns over } \\
\text { nanotoxicity; } \\
\text { concerns over } \\
\text { storage stability; } \\
\text { poor PK }\end{array}$ \\
\hline $\begin{array}{l}\text { Polymer-drug } \\
\text { Conjugate }\end{array}$ & $\begin{array}{l}\text { Covalent } \\
\text { conjugation using } \\
\text { stimuli-responsiv } \\
\text { e linkers, such as } \\
\text { pH-sensitive } \\
\text { linker, disulfide } \\
\text { and enzymatic } \\
\text { degradable linker }\end{array}$ & $\begin{array}{l}\text { Easy scale up; high drug } \\
\text { loading; improved PK; } \\
\text { reduced side effects; } \\
\text { improved patient } \\
\text { compliance; stimulated } \\
\text { release in tumor thruogh } \\
\text { variable linkers }\end{array}$ & $\begin{array}{l}\text { Slow hydrolysis; } \\
\text { reduced bioactivity }\end{array}$ \\
\hline $\begin{array}{l}\text { Liposomal } \\
\text { formulation }\end{array}$ & $\begin{array}{l}\text { Self-assembly; } \\
\text { remote loading } \\
\text { from } \mathrm{pH} \text { gradients }\end{array}$ & $\begin{array}{l}\text { Biocompatible; reduction } \\
\text { of side effects without } \\
\text { compromising drug } \\
\text { efficacy; suitable for } \\
\text { delivery of drugs with } \\
\text { diverse properties; } \\
\text { suitable to various } \\
\text { administration routes }\end{array}$ & $\begin{array}{l}\text { Limited drug } \\
\text { loading; poor shelf } \\
\text { stability; high cost; } \\
\text { complex } \\
\text { sterilization } \\
\text { process; slow } \\
\text { release for } \\
\text { hydrophobic drug }\end{array}$ \\
\hline Nanocrystals & $\begin{array}{l}\text { Nanoprecipitation } \\
\text {; milling } \\
\text { technology; } \\
\text { high-pressure } \\
\text { homogenization }\end{array}$ & $\begin{array}{l}\text { Easy to scale up; reliable } \\
\text { manufacturing quality; } \\
\text { suitable for hydrophobic } \\
\text { drugs with various } \\
\text { properties; faster } \\
\text { dissolution rate; improved } \\
\text { bioavialability via oral } \\
\text { delivery }\end{array}$ & $\begin{array}{l}\text { High energy input; } \\
\text { requires surfactant; } \\
\text { lack of controlled } \\
\text { release; not suitable } \\
\text { for intraveneous } \\
\text { administration }\end{array}$ \\
\hline $\begin{array}{l}\mathrm{LCP} \\
\text { nanoparticles }\end{array}$ & $\begin{array}{l}\text { Reaction based } \\
\text { nanoprecipitation } \\
\text { in microemulsion }\end{array}$ & $\begin{array}{l}\text { Ablility to encapsulate } \\
\text { drugs with diverse } \\
\text { properties without } \\
\text { compromising drug } \\
\text { efficacy; improved PK; } \\
\text { small size; biodegradable; } \\
\text { efficient drug } \\
\text { encapsulation }\end{array}$ & $\begin{array}{l}\text { Use of surfactant; } \\
\text { relatively } \\
\text { complicated } \\
\text { manufacturing } \\
\text { process; }\end{array}$ \\
\hline $\begin{array}{l}\text { Inorganic } \\
\text { nanoparticles }\end{array}$ & $\begin{array}{l}\text { Covalent } \\
\text { conjugation; } \\
\text { nanoprecipition; } \\
\text { self assembly }\end{array}$ & $\begin{array}{l}\text { Easily prepared with } \\
\text { controllable size; surface } \\
\text { functionalization; unique } \\
\text { optical, electrical and } \\
\text { physical properties }\end{array}$ & $\begin{array}{l}\text { Concerns over } \\
\text { nanotoxicity; few } \\
\text { clinical } \\
\text { applications; no } \\
\text { FDA approved } \\
\text { nanomedicines; not } \\
\text { biodegradable }\end{array}$ \\
\hline $\begin{array}{l}\text { Solid lipid } \\
\text { nanoparticles }\end{array}$ & $\begin{array}{l}\text { High shear } \\
\text { homogenization } \\
\text { and ultrasound; } \\
\text { high pressure } \\
\text { homogenization; } \\
\text { solvent } \\
\text { emulsification/ev } \\
\text { aporation }\end{array}$ & $\begin{array}{l}\text { No use of organic } \\
\text { solvents; suitable to } \\
\text { administer via various } \\
\text { routes; established } \\
\text { production method; } \\
\text { controlled release; } \\
\text { improved bioavailability; } \\
\text { high drug payload }\end{array}$ & $\begin{array}{l}\text { Particle growth; } \\
\text { unpredictable } \\
\text { gelation tendency; } \\
\text { unexpected } \\
\text { dynamics of } \\
\text { polymeric } \\
\text { transitions; } \\
\text { occasional burst } \\
\text { release observed }\end{array}$ \\
\hline
\end{tabular}


Table 2

Nanomedicines on the market and under clinical evaluation.

\begin{tabular}{|c|c|c|c|c|}
\hline & Agent & Formulation & Company & Indication and Status \\
\hline \multirow[t]{6}{*}{$\begin{array}{l}\text { Polymeric } \\
\text { nanoparticles }\end{array}$} & $\begin{array}{l}\text { Genexol-P } \\
\mathrm{M}{ }^{\circledR}\end{array}$ & $\begin{array}{l}\text { polymeric nanoparticles } \\
\text { (mPEG-PDLLA) } \\
\text { formulation of paclitaxel }\end{array}$ & Samyang Co. & $\begin{array}{l}\text { Approved in Asia for treatment of breast and lung } \\
\text { cancers (Lee, Chung, 2008b; Lim, Tan, 2010); } \\
\text { Combinational therapy with gemcitabine and } \\
\text { cisplatin to treat advanced urothelial cancer currently } \\
\text { in Phase II clinical trial (Lee, Ahn, 2012a) }\end{array}$ \\
\hline & $\begin{array}{l}\text { Docetaxel-P } \\
\text { NP }\end{array}$ & $\begin{array}{l}\text { polymeric nanoparticles } \\
\text { (mPEG-PDLLA) } \\
\text { formulation of docetaxel }\end{array}$ & Samyang Co. & $\begin{array}{l}\text { Treat advanced solid malignancies (Miller and Wang, } \\
\text { 2013; Svenson, 2012) }\end{array}$ \\
\hline & BIND-014 & $\begin{array}{l}\text { PEG-PLGA-PMSA-target } \\
\text { ed polymeric nanoparticle } \\
\text { formulation of docetaxel }\end{array}$ & $\begin{array}{l}\text { Bind } \\
\text { Biosciences, Inc. }\end{array}$ & $\begin{array}{l}\text { Usage for treating advanced or metastatic cancer } \\
\text { currently in Phase I clinical trial (Cartwright, 2013; } \\
\text { Prabhakar, Blakey, 2013; Wang, Langer, 2012) }\end{array}$ \\
\hline & NK-105® & $\begin{array}{l}\text { Polymeric micellar } \\
\text { (Poly(ethylene } \\
\text { glycol)-copoly(L-aspartic } \\
\text { acid)) formulation of } \\
\text { paclitaxel }\end{array}$ & $\begin{array}{l}\text { NanoCarrier/Nip } \\
\text { pon Kayaku }\end{array}$ & $\begin{array}{l}\text { Usage for treatment of solid tumors currenlty in } \\
\text { Phase II clinical trial (Japan) }\end{array}$ \\
\hline & Abraxane ${ }^{\circledR}$ & $\begin{array}{l}\text { Albumin-bound paclitaxel } \\
\text { nanoparticle }\end{array}$ & Celgene Corp. & $\begin{array}{l}\text { Used to treat metastatic breast cancer, Marketed (US, } \\
\text { EU) }\end{array}$ \\
\hline & SP1049C & $\begin{array}{l}\text { polymeric nanoparticles } \\
\text { (poloxamer) formulation of } \\
\text { doxorubicin }\end{array}$ & $\begin{array}{l}\text { Supratek } \\
\text { Pharma Inc. }\end{array}$ & $\begin{array}{l}\text { Usage for treating non-resectable stage IVb } \\
\text { adenocarcinoma currently in Phase II clinical trial } \\
\text { (UK) (Valle, Armstrong, 2011) }\end{array}$ \\
\hline \multirow[t]{6}{*}{$\begin{array}{l}\text { Polymer-drug } \\
\text { conjugate }\end{array}$} & $\begin{array}{l}\text { PK1, } \\
\text { FCE28068 }\end{array}$ & $\begin{array}{l}\text { Polymer } \\
\text { (HPMA)-doxorubicin } \\
\text { conjugate }\end{array}$ & $\begin{array}{l}\text { Pharmacia and } \\
\text { Upjohn }\end{array}$ & $\begin{array}{l}\text { Usage for treating breast, lung and colorectal cancer } \\
\text { currently in Phase II (UK) (Seymour, Ferry, 2009) }\end{array}$ \\
\hline & Xyotax & $\begin{array}{l}\text { poly glutamic acid } \\
\text {-paclitaxel conjugates }\end{array}$ & $\begin{array}{l}\text { Cell } \\
\text { Therapeutic, Inc }\end{array}$ & $\begin{array}{l}\text { Combination with Gemcitabin or Vinorelbine to treat } \\
\text { Naïve Advanced Non-small Cell Lung Cancer in } \\
\text { currently in Phase III clinical trial (O'Brien, Socinski, } \\
\text { 2008) }\end{array}$ \\
\hline & CT-2106 & $\begin{array}{l}\text { poly glutamic acid - } \\
\text { camptothecin conjugates }\end{array}$ & $\begin{array}{l}\text { Cell } \\
\text { Therapeutic, Inc }\end{array}$ & $\begin{array}{l}\text { Treatment for advanced solid malignancies currently } \\
\text { in Phase I clinical trial (Homsi, Simon, 2007) }\end{array}$ \\
\hline & $\begin{array}{l}\text { CRLX101 } \\
\text { (IT-101) }\end{array}$ & $\begin{array}{l}\text { beta-CD-PEG-camptotheci } \\
\text { n nanopharmaceutical }\end{array}$ & $\begin{array}{l}\text { Cerulean } \\
\text { Pharma Inc. }\end{array}$ & $\begin{array}{l}\text { Usage for treatment of advanced NSCLC currently in } \\
\text { Phase II clinical trial }\end{array}$ \\
\hline & $\begin{array}{l}\text { Delimoteca } \\
\text { n (MEN } \\
\text { 4901/T-012 } \\
\text { 8) }\end{array}$ & $\begin{array}{l}\text { Polysaccharide-drug } \\
\text { conjugate } \\
\text { (10-(3'-amino-propyloxy)- } \\
\text { 7-ethyl-(20S)-camptotheci } \\
\text { n) }\end{array}$ & $\begin{array}{l}\text { Berlin-Chemie } \\
\text { AG }\end{array}$ & $\begin{array}{l}\text { Usage for treatment for solid tumors currently in } \\
\text { Phase I clinical trial (Netherland) (Veltkamp, Witteveen, } \\
\text { 2008) }\end{array}$ \\
\hline & MTX-HSA & $\begin{array}{l}\text { Methotrexate-albumin } \\
\text { conjugate }\end{array}$ & $\begin{array}{l}\text { Klinge Pharma } \\
\text { GmbH }\end{array}$ & $\begin{array}{l}\text { Combination with cisplatin to treat advanced or } \\
\text { metastatic transitional cell carcinoma } \\
\text { (Finland)(Bolling, Graefe, 2006) }\end{array}$ \\
\hline \multirow[t]{5}{*}{$\begin{array}{l}\text { Liposomal } \\
\text { formulation }\end{array}$} & $\begin{array}{l}\text { Doxil®/ } \\
\text { Caelyx }{ }^{\circledR}\end{array}$ & $\begin{array}{l}\text { PEGylated liposomal } \\
\text { doxorubicin }\end{array}$ & $\begin{array}{l}\text { Janssen } \\
\text { Pharmaceuticals }\end{array}$ & $\begin{array}{l}\text { Treats Kaposi's sarcoma; metastatic breast \&ovarian } \\
\text { cancers, FDA approved (Barenholz, 2012) }\end{array}$ \\
\hline & $\begin{array}{l}\text { DaunoXom } \\
\mathrm{e} \AA\end{array}$ & Liposomal daunorubicin & Galen Ltd. & $\begin{array}{l}\text { Treats HIV-associated Kaposi's sarcoma, FDA } \\
\text { approved (Fassas and Anagnostopoulos, 2005) }\end{array}$ \\
\hline & Myocet $\AA$ & Liposomal doxorubicin & $\begin{array}{l}\text { Cephalon Inc. } \\
\text { (EU)/ Sopherion } \\
\text { Therapeutics } \\
\text { (US, CAN) }\end{array}$ & $\begin{array}{l}\text { Treats metastatic breast cancer, Marketed (EU) } \\
\text { (Leonard et al., 2009) }\end{array}$ \\
\hline & $\begin{array}{l}\text { MM-398 } \\
\text { (PEP02) }\end{array}$ & Liposomal irinotecan & $\begin{array}{l}\text { Merrimack } \\
\text { Pharmaceuticals } \\
\text {, Inc. }\end{array}$ & $\begin{array}{l}\text { Treatment for metastatic pancreatic cancer, currently } \\
\text { in Phase } 3 \text { clinical trial (Ko, Tempero, 2013; Roy et al., } \\
\text { 2013) }\end{array}$ \\
\hline & OSI-211 & Liposomal lurtotecan & $\begin{array}{l}\text { Astellas Pharma } \\
\text { Inc. }\end{array}$ & $\begin{array}{l}\text { Treatment for recurrent small cell lung cancer, } \\
\text { currenlty in Phase } 2 \text { clinical trial (Duffaud et al., 2004) }\end{array}$ \\
\hline
\end{tabular}




\begin{tabular}{|l|l|l|l|l|}
\hline & Agent & Formulation & Company & Indication and Status \\
\hline & $\begin{array}{l}\text { ThermoDox } \\
\circledR\end{array}$ & $\begin{array}{l}\text { Heat-sensitive liposomal } \\
\text { doxorubicin }\end{array}$ & Celsion Corp. & $\begin{array}{l}\text { Treatment for primary liver cancer, currenlty in Phase } \\
\text { 3 clinical trial (Dromi et al., 2007) }\end{array}$ \\
\cline { 2 - 5 } & LEP-ETU & Liposomal paclitaxel & $\begin{array}{l}\text { Insys } \\
\text { Therapeutics, } \\
\text { Inc. }\end{array}$ & $\begin{array}{l}\text { Treatment for metastatic breast cancer, currently in } \\
\text { Phase 2 (Koudelka and Turanek, 2012) }\end{array}$ \\
\hline Nanocrystal & $\begin{array}{l}\text { Panzem®N } \\
\text { CD }\end{array}$ & $\begin{array}{l}\text { Nanocrystal formulation of } \\
\text { 2-methoxyestradiol }\end{array}$ & EntreMed & $\begin{array}{l}\text { Treatment for Metastatic carcinoid tumors, currently } \\
\text { in Phase II clinical trial (Bruce et al., 2012; Kulke et al., } \\
\text { 2011) }\end{array}$ \\
\cline { 2 - 5 } & Theralux ${ }^{\mathrm{TM}}$ & $\begin{array}{l}\text { Nanocrystal formulation of } \\
\text { thymectacin }\end{array}$ & Celmed & $\begin{array}{l}\text { Treats metastatic breast cancer, Marketed (US, EU) } \\
\text { (Shegokar and Muller, 2010) }\end{array}$ \\
\hline
\end{tabular}

